\title{
TRANSFORMATIONS IN ORGANIC SULFUR SPECIATION DURING MATURATION OF MONTEREY SHALE: CONSTRAINTS FROM LABORATORY EXPERIMENTS
}

\author{
Bryan C. Nelson ${ }^{1}$, Timothy I. Eglinton ${ }^{1}$, Jeffrey S. Seewald ${ }^{1}$, \\ Murthy A. Vairavamurthy' ${ }^{2}$, Francis P. Miknis ${ }^{3}$
}

'Dept. of Marine Chemistry and Geochemistry, Woods Hole Oceanographic Institution, Woods Hole MA, 02543

${ }^{2}$ Applied Physical Sciences Division Dept. of Applied Science, Brookhaven National Laboratory, Upton, NY 11973

${ }^{3}$ Western Research Institute, Laramie, WY 82071

Submitted to an ACS Symposium Series Volume

GEOCHEMICAL TRANSFORMATIONS OF SEDIMENTARY SULFUR

(in press)

April 1995

By acceptance of this article, the publisher and/or recipient acknowledges the U.S. Government's right to retain a nonexclusive, royalty-free licence in and to any copyright covering this paper.

This research was performed under the auspices of the U.S. Department of Energy Division of Engineering and Geosciences of the Office of the Basic Energy Sciences (Brookhaven National Laboratory Contract No. DE-AC02-76CH00016). 


\section{DISCLAIMER}

This report was prepared as an account of work sponsored by an agency of the United States Government. Neither the United States Government nor any agency thereof, nor any of their employees, makes any warranty, express or implied, or assumes any legal liability or responsibility for the accuracy, completeness, or usefulness of any information, apparatus, product, or process disclosed, or represents that its use would not infringe privately owned rights. Reference herein to any specific commercial product, process, or service by trade name, trademark, manufacturer, or otherwise does not necessarily constitute or imply its endorsement, recommendation, or favoring by the United States Government or any agency thereof. The views and opinions of authors expressed herein do not necessarily state or reflect those of the United States Government or any agency thereof. 


\section{DISCLAIMER}

Portions of this document may be illegible in electronic image products. Images are produced from the best available original document. 


\title{
Transformations in Organic Sulfur Speciation During Maturation of Monterey Shale: Constraints from Laboratory Experiments
}

\author{
Bryan C. Nelson', Timothy I. Eglinton', Jeffrey S. Seewald', \\ Appathurai Vairavamurthy ${ }^{2}$, Francis P. Miknis ${ }^{3}$ \\ ${ }^{1}$ Dept. of Marine Chemistry and Geochemistry, Woods Hole Oceanographic \\ Institution, Woods Hole MA, 02543 \\ ${ }^{2}$ Dept. of Applied Science, Brookhaven National Laboratory, Upton, NY 11973, \\ ${ }^{3}$ Western Research Institute; Laramie, WY 82071
}

\begin{abstract}
A series of hydrous pyrolysis experiments were conducted at temperatures ranging from 125 to $360^{\circ} \mathrm{C}$ at 350 bars pressure to examine variations in sulfur speciation during thermal maturation of Monterey shale. The total sediment, kerogen and bitumen from each experiment in addition to unheated representatives were analyzed via $\mathrm{x}$-ray absorption spectroscopy, pyrolysis-gas chromatography, ${ }^{13} \mathrm{C}$ NMR spectrometry, elemental analysis, thin-layer chromatography and reflected light microscopy.

Based on these measurements, it was possible to recognize three distinct temperature regimes, within which the type and amount of sulfur in the analyzed fractions underwent transformations: (i) between 150 and $225^{\circ} \mathrm{C}$, a significant proportion of kerogen-bound sulfur is lost probably due to the collapse of polysulfide bridges; (ii) between 225 and $275^{\circ} \mathrm{C}$, cleavage of -S-S- and -S-C- linkages within the kerogen is believed to occur, resulting in substantial production of polar sulfur-rich bitumen; (iii) above $275^{\circ} \mathrm{C}$ total bitumen yields as well as the proportion of bitumen sulfur decrease, while $\mathrm{C}-\mathrm{C}$ bond scission leads to increased yields of saturated and aromatic hydrocarbons.

The results from this study clearly and quantitatively establish a link between organically-bound sulfur, and more specifically, organic polysulfides, and the low-temperature evolution of soluble petroleum-like products (bitumen) from sulfur-rich source rocks.
\end{abstract}

There have been numerous investigations of the effects of heteroatoms (atoms other than carbon and hydrogen) in kerogen on the timing and thermal stress required for petroleum generation $(1-3)$. In particular, the role of sulfur during petroleum generation has received a great deal of attention (3-8). These studies typically attributed early petroleum generation from sulfur-rich kerogens to the inherent 
weakness of sulfur-sulfur and sulfur-carbon bonds relative to carbon-carbon bonds (9). Studies of the role of sulfur in the sedimentary formation of kerogen (10-12) suggest that sulfur linkages must be ubiquitous in sulfur-rich Type II-S kerogens $\left(\mathrm{S}_{\text {org }} / C>0.04:(5)\right)$. These inferences implicating sulfur in maturation, however, are based largely on indirect and circumstantial evidence and the connection between the chemistry of sulfur-rich kerogens and the physical processes leading to petroleum generation remain unclear (13).

The goal of this study was to gain further insight into the chemical changes involving sulfur during source rock maturation. In contrast to previous studies, emphasis was placed on direct assessment of the changes in sulfur species in the organic matter itself. A series of hydrous-pyrolysis experiments were conducted with sulfur-rich Monterey shale at temperatures ranging from 125 to $360^{\circ} \mathrm{C}$ to provide constraints on the speciation of sulfur in kerogen and generated products as a function of temperature. Although, temperatures higher than those found in natural settings are employed during hydrous-pyrolysis (in order to enhance reaction rates and allow organic transformations to be observed on a laboratory time scale), these experiments have proven an effective means to simulate the generation of hydrocarbons in the laboratory. Previous studies have shoun that the pyrolysisproducts are similar to products of geological maturation (3.14). In addition, the processes leading to the generation and expulsion of oil during hydrous-pyrolysis experiments appear to be the same as those occurring in natural petroleum formation (14).

An analytical scheme was designed to facilitate a mass-balance approach involving gaseous, liquid (bitumen) and solid (altered sediment and kerogen) phases that allowed a detailed characterization of the fate of organic sulfur during thermal maturation. Analyses were conducted using $\mathrm{x}$-ray absorption near edge structure (XANES) spectroscopy, pyrolysis-gas chromatography (Py-GC), solid-state ${ }^{13} \mathrm{C}$ nuclear magnetic resonance (NMR) spectrometry, thin-layer chromatography with flame ionization detection (TLC-FID), elemental analyses and reflected light microscopy. This blend of analyses enabled the determination of gross and molecular-level transformations in sulfur speciation, as well as the manner by which they lead to the early conversion of kerogen to oil.

\section{Experimental}

Sample Description and Preparation. A thermally immature $\left(\mathrm{R}_{\mathrm{o}}=0.25 \%\right)$ consolidated sediment sample from the Miocene Monterey Fm. (ML91-17) was obtained from an outcrop at Naples Beach, CA. The sample was removed from a $10 \mathrm{~cm}$ interval at the base of Unit 315, approximately $9 \mathrm{~m}$ below the lowest phosphorite horizon (M.D. Lewan, personal communication). The sample comprised a lenticularly laminated claystone and visually appeared fresh (i.e. unweathered) and blocky. The surface of the sample was scraped prior to disc-mill pulverization to expose pristine material and remove possible contaminants.

Figure 1 illustrates the experimental scheme used in this siudy. Our primary goal was to examine the fate of kerogen-bound sulfur during artificial maturation. Consequently, after pulverization. the sediment sample was sequentially extracted 
by sonic disruption using $\mathrm{CH}_{3} \mathrm{OH} / \mathrm{CHCl}_{3}$ to remove indigenous bitumen. Sedimentary carbonate was removed from the sample by treating with $10 \% \mathrm{HCl}$ at $40^{\circ} \mathrm{C}$ for $2 \mathrm{hrs}$. For each experiment $1.0 \mathrm{~g}$ of solvent-extracted. carbonate-free sediment was used as the starting material except for the experiments at 225 and $275^{\circ} \mathrm{C}$, in which carbonate was not removed from the staring material. The sediment sample was loaded into a $20 \mathrm{~mL}$ ( $30.5 \times 0.9 \mathrm{~cm}$ i.d.) pipe-bomb, sealed and placed into a $62 \times 12.0 \mathrm{~cm}$ i.d. furnace. The pipe-bomb was evacuated and then partially filled with argon-purged distilled water to ensure that the sediment was in contact with water during heating. Once at the experimental temperature, the pipebomb was filled completely with distilled water and pressurized to 350 bars so that only a single liquid phase was present (i.e., no head-space). Temperature was monitored $\left( \pm 2^{\circ} \mathrm{C}\right)$ with a thermocouple at each end of the pipe-bomb to ensure there were no thermal gradients. All experiments were $168 \mathrm{hrs}$ in duration.

During an experiment, fluid samples were withdrawn from the pipe-bomb through a $10 \mu \mathrm{m}$ filter into glass gas-tight syringes after approximately 24,72 and $168 \mathrm{hrs}$ and analyzed for the gas concentrations of dissolved gases. Pressure was maintained during the sampling process by pumping argon-purged distilled water into one end of the pipe-bomb while the fluid sample was removed from the other. The sampling process was performed rapidly (1 to $2 \mathrm{~min}$ ) to avoid dilution of the fluid samples with the freshly injected water. At the end of the experiment the pipebomb was cooled and all liquid contents were removed by sequentially pumping 30 $\mathrm{mL}$ of $\mathrm{CH}_{3} \mathrm{OH}$ and $\mathrm{CH}_{2} \mathrm{Cl}_{2}$ through the pipe-bomb. Subsequently. the pipe-bomb was opened and the solid residue was removed by rinsing with additional solvent. The combined $\mathrm{CH}_{3} \mathrm{OH} / \mathrm{CH}_{2} \mathrm{Cl}_{2}$ extract was centrifuged and the liquid products decanted. After drying at $40^{\circ} \mathrm{C}$ in air, the solid residue was sequentially extracted by sonic disruption in $\mathrm{CH}_{3} \mathrm{OH} / \mathrm{CH}_{2} \mathrm{Cl}_{2}$ to ensure complete recovery of the generated bitumen. This extract was combined with the pipe-bomb rinses, back-extracted with distilled $\mathrm{H}_{2} \mathrm{O}$, dried over anhydrous $\mathrm{Na}_{2} \mathrm{SO}_{4}$ and filtered $(0.45 \mu \mathrm{m})$ to remove residual suspended material yielding the generated bitumen. A split of the altered sediment $(\sim 350 \mathrm{mg})$ was demineralized through $\mathrm{HCl}$ and $\mathrm{HF}$ acid digestions at room temperature (15) to obtain a kerogen isolate. An aliquot $(-50 \mathrm{mg})$ of the kerogen isolate was treated with $\mathrm{CrCl}_{2}$ and concentrated $\mathrm{HCl}$ to remove inorganic sulfur $(16,17)$.

Gas Analysis. Dissolved $\mathrm{CO}_{2}$ and light $\left(\mathrm{C}_{1}-\mathrm{C}_{6}\right)$ hydrocarbons in the fluid samples from all experiments were analyzed using a purge and trap apparatus interfaced to a gas chromatograph. Dissolved $\mathrm{H}_{2} \mathrm{~S}$ concentrations were monitored to obtain an estimate of the amount of sulfur, both inorganic and organic, removed from the system as $\mathrm{H}_{2} \mathrm{~S}$ during sediment maturation. The absolute concentration of dissolved $\mathrm{H}_{2} \mathrm{~S}$ was determined gravimetrically by precipitation as $\mathrm{Ag}_{2} \mathrm{~S}$ in a $3{ }^{\prime} \mathrm{t} \% \mathrm{AgNO}_{3}$ solution.

Elemental Analysis. Elemental analyses were performed in order to monitor fluctuations in the distribution of sulfur and carbon among the various fractions resulting from maturation of the Monterey shale. Weight percent C. H. $N$ and $S$ 
were determined for all fractions including those obtained from unheated. solventextracted Monterey shale. Elemental analyses were conducted using a Leco 932 elemental analyzer.

X-ray Absorption Spectroscopy (XANES). X-ray Absorption Near Edge Structure (XANES) Spectroscopy was performed at the National Synchrotron Light Source at Brookhaven National Laboratory on Beamline X-19A $(18,19)$. XANES was conducted on the unheated and altered sediments, bitumen, and $\mathrm{CrCl}_{2}$-treated kerogens to observe thermally-induced changes in sulfur speciation within and between the various fractions. Solid samples were prepared as boric acid pellets, whereas liquid samples were taken to near dryness and adsorbed onto precombusted GF/F filters under a $\mathrm{N}_{2}$ atmosphere, heat-sealed in air-tight pouches and kept frozen prior to analysis. Solid and liquid samples were analyzed while mounted in a He-purged sample chamber. XANES spectra of all fractions were acquired from 2465 to $2900 \mathrm{eV}$ using a Lytle fluorescence detector. A monochromator step function was chosen to provide a resolution of $0.5 \mathrm{eV}$ at the near-edge region.

Quantitative deconvolution of the XANES spectra was accomplished using a computer algorithm developed by Waldo et al. (20). After corrections to account for background and self-absorption, the proportions of different sulfur species were calculated by fitting the normalized spectra (least-squares procedure) with up to six reference-compound spectra. For this study, $\mathrm{FeS}_{2}$, elemental sulfur, cysteic acid, sodium sulfate, benzyl sulfide, dibenzyl trisulfide, dibenzothiophene and dibenzylsulfoxide were used as reference compounds. The accuracy of these results are estimated to be $\pm 10 \%$. Optimal curve-fitting of the XANES spectra from analyses of altered sediments and kerogens prior to $\mathrm{CrCl}_{2}$ treatment was difficult due to the presence of inorganic sulfur compounds (pyrite). Consequently, sulfur speciation determinations are reported only for the bitumen and $\mathrm{CrCl}_{2}$-treated kerogen.

Analytical Pyrolysis (Py-GC). Analytical pyrolysis was conducted to determine the relative distribution of volatile thiophenic and hydrocarbon pyrolysis-products from the kerogen and pyrite-free kerogen samples from the unheated and matured Monterey Shale. Pyrolysis-Gas Chromatography was performed using a FOM-3LX Curie-point pyrolysis unit (controlled by a Horizon RF generator) interfaced to a Hewlett-Packard 5890 Series II GC (18). Kerogen samples were loaded onto Fe/Ni wires with a Curie temperature of $610^{\circ} \mathrm{C}$. Samples were pyrolyzed for $5 \mathrm{~s}$ and the pyrolysis interface temperature was set at $200^{\circ} \mathrm{C}$. Helium was used as the carrier gas. Separation of the pyrolysis products was achieved on a Restek $R_{T X .1}$ column ( $50 \mathrm{~m} \times 0.32 \mathrm{~mm}$ i.d.; film thickness $0.5 \mu \mathrm{m}$ ) using a temperature program from $30^{\circ} \mathrm{C} \mathrm{(5} \mathrm{min} \mathrm{initial} \mathrm{time)} \mathrm{to} 320^{\circ} \mathrm{C}\left(15 \mathrm{~min}\right.$ final time) at a rate of $3^{\circ} \mathrm{C} \mathrm{min}{ }^{-1}$. The GC effluent was split and simultaneously monitored by a flame ionization detector (FID) and a sulfur-selective flame photometric detector (FPD). Flash pyrolysis of the kerogen and pyrite-free kerogen fractions yielded near-identical results, 
indicating that the $\mathrm{CrCl}_{2}$-treatment did not affect the relative distribution of GCamenable (i.e. volatile) products analyzed.

Nuclear Magnetic Resonance (NMR) Spectrometry. Solid-state ${ }^{13} \mathrm{C}$ NMR spectrometry was used to determine changes in the carbon structure of the altered sediments, kerogens and $\mathrm{CrCl}_{2}$-treated kerogens that occurred as a result of thermal maturation. Solid-state ${ }^{13} \mathrm{C}$ NMR measurements were made using the technique of cross polarization (CP) with magic-angle spinning (MAS) at a carbon frequency of $25 \mathrm{MHz}$ using a ceramic probe and a $7.5 \mathrm{~mm}$ o.d. zirconia pencil rotor. As a consequence of the small amounts of sample material available for the NMR measurements ( $\sim 20 \mathrm{mg}$ for the kerogens and $\sim 100 \mathrm{mg}$ for the altered sediments), data were collected over periods of 15 to $18 \mathrm{hrs}(54,000$ and 64,800 transients). A pulse delay of $1 \mathrm{~s}$, a contact time of $1 \mathrm{~ms}$, a $5.0 \mu \mathrm{s}$ pulse width and a sweep width of $16 \mathrm{kHz}$ were used to acquire data. Sample spinning speeds were $\sim 4.5 \mathrm{kHz}$. A 50 $\mathrm{Hz}$ exponential multiplier was applied to the free induction decay of each ${ }^{13} \mathrm{C}$ spectrum before integration.

The NMR spectra were integrated between 90 and $260 \mathrm{ppm}$ for the "aromatic" region and -40 to $90 \mathrm{ppm}$ for the "aliphatic" region. The spinning rates were sufficiently high so that contributions to the aliphatic integrals from high field aromatic carbon spinning sidebands were negligible and were not included in the aliphatic carbon integrals. The carbon aromaticity values can contain contributions from carbonyl ( $-210 \mathrm{ppm})$ and carboxyl carbons $(\sim 180 \mathrm{ppm})$, if present.

Bituminite Reflectance. Microscopic examination of the initial (unheated) sediment sample revealed that the majority of organic matter was comprised of an amorphous groundmass termed "bituminite" $(2 I)$, with only trace amounts of recognizable vitrinite. Bituminite, which is believed to derive from degraded algal and bacterial matter, is thus considered to be a major kerogen constituent. For this reason, and because vitrinite is so scarce, direct measurements of reflectance were made on bituminite in order to assess the extent of thermal alteration.

Thin-layer Chromatography. Quantification of the saturated, aromatic and polar compound classes in the bitumen was performed by thin-layer chromatography with flame ionization detection (TLC-FID) according to the methods of Karlsen and Larter (22) using an Iatroscan TH-10 Mark III instrument. 1.5-2.0 $\mu \mathrm{L}$ of each sample (dissolved in $\mathrm{CH}_{2} \mathrm{Cl}_{2}$ ) was applied to silica rods which were sequentially developed in $\mathrm{C}_{6} \mathrm{H}_{14}(10 \mathrm{~cm}), \mathrm{C}_{7} \mathrm{H}_{8}(5 \mathrm{~cm})$ and a $95: 5$ solution of $\mathrm{CH}_{2} \mathrm{Cl}_{2}: \mathrm{CH}_{3} \mathrm{OH}(2$ $\mathrm{cm})$. A standard mixture comprised of $n$-eicosane, dibenzothiophene and 2,6dimethoxyphenol was used for calibration of response factors for aliphatic, aromatic and polar compounds, respectively. 


\section{Results}

Gaseous Phases. Dissolved $\mathrm{H}_{2} \mathrm{~S}$ concentrations were measured during five of the hydrous-pyrolysis experiments (Table 1). During these experiments the concentration of dissolved $\mathrm{H}_{2} \mathrm{~S}$ was likely controlled by the solubility of iron sulfides such as pyrite and/or pyrrhotite owing to the rapid precipitation/dissolution kinetics for these phases under hydrothermal conditions (23). Pyrite was abundant in the unheated sediment and persisted along with newly formed pyrnhotite in the thermally altered sediments. At temperatures below $225^{\circ} \mathrm{C}$ dissolved $\mathrm{H}_{2} \mathrm{~S}$ concentrations were too low to be determined gravimetrically, but $\mathrm{H}_{2} \mathrm{~S}$ was detectable by odor in all experiments. Sources of dissolved $\mathrm{H}_{2} \mathrm{~S}$ during the experiments include diagenetic pyrite and organic sulfur. It is not possible to directly determine the relative contributions from these two sources based on dissolved concentrations alone. However, at 350 and $360^{\circ} \mathrm{C} 12.7$ and $18.8 \mathrm{mg}$ $\mathrm{H}_{2} \mathrm{~S} / \mathrm{g}$ rock was released to solution respectively. These amounts exceed the amount of sulfur present as diagenetic pyrite in the initial sediment $(10.5 \mathrm{mg} / \mathrm{g}$ sediment), and thereby provide direct evidence for the release of organically bound sulfur to solution. Because dissolved sulfide is cycled through the fluid into sulfide minerals, the calculated contributions of organic sulfur to solution represent an absolute minimum.

Generated Bitumen. The total bitumen extract, saturated, aromatic and polar compound yields from each experiment and the indigeneous material removed from the sample prior to heating, are listed in Table 1 and illustrated in Figure 2. The initial bitumen content of the unheated sediment was approximately $11 \mathrm{mg} / \mathrm{g}$ rock. We estimate an extraction efficiency of $>70 \%$ in removing this bitumen from the starting material, and hence any contribution from indigenous bitumen to extractable yields after the experiments is likely to be minor. In all cases, polar compounds comprised the majority of each bitumen fraction and, as a result, the total extract largely mirrored polar compound yields. The yield of polars increased with temperature to a maximum in the $275^{\circ} \mathrm{C}$ experiment $(62.0 \mathrm{mg} / \mathrm{g}$ rock), above which concentrations decreased. The yield of saturate and aromatic compounds were similar to each other with maxima in the experiments at temperatures above $275^{\circ} \mathrm{C}$.

The results of the elemental analyses $(\mathrm{C}, \mathrm{H}, \mathrm{N}$ and $\mathrm{S})$ of the bitumen are listed in Table 2. Above $250^{\circ} \mathrm{C}$ the atomic ratio of hydrogen to carbon $(\mathrm{H} / \mathrm{C})$ decreased while the atomic ratio of nitrogen to carbon (N/C) remained relatively constant. Above $150^{\circ} \mathrm{C}$ the bitumen initially exhibited an increase in the sulfur to carbon $(\mathrm{S} / \mathrm{C})$ ratio with temperature which reached a maximum at $250^{\circ} \mathrm{C}$ followed by a decrease (Figure 3).

Normalized (K-edge) XANES spectra of the bitumen are illustrated in Figure 4. Reduced sulfur species (sulfides) are represented by peaks that occur towards the left side of each spectra, whereas peaks for more oxidized species (sulfoxides) are found at higher energies. Fitting of the XANES spectra reveal that organic sulfides and polysulfides were the primary sulfur forms contained in the bitumen and 
typically accounted for over $50 \%$ of the sulfur present (Figure 5). The remaining sulfur was in the form of thiophenes and sulfoxides. Thiophenes and sulfoxides exhibited relatively little change with temperature, while organic sulfides and polysulfides increased significantly from $3 \%$ to a maximum of $8 \%$ of the bitumen at $275^{\circ} \mathrm{C}$. Above this temperature the weight percent of sulfides and polysulfides in the bitumen decreased.

Solid Phases. In the altered sediments, weight percent organic carbon, nitrogen and sulfur as well as the $\mathrm{S} / \mathrm{C}$ atomic ratio, decreased with increasing temperature (Table 2). In the kerogens the $\mathrm{H} / \mathrm{C}$ atomic ratio decreased at higher temperatures $\left(>250^{\circ} \mathrm{C}\right)$ while the N/C atomic ratio remained fairly constant. In contrast to the bitumen, the $\mathrm{S} / \mathrm{C}$ ratio of the kerogen initially decreased with increasing temperature (Figure 3 ). This decrease was first apparent in kerogens from experiments above $175^{\circ} \mathrm{C}$, with the $\mathrm{S} / \mathrm{C}$ ratio changing from -0.05 to $<0.02$ in kerogen from experiments above $300^{\circ} \mathrm{C}$. Between 325 and $360^{\circ} \mathrm{C}$, the $\mathrm{S} / \mathrm{C}$ ratio remained constant.

Bituminite reflectance measurements of the altered sediments are listed in Table 3 and illustrated in Figure 6 . The reflectance value of the bituminite present in the altered sediment were low $(0.25 \%)$, relative to vitrinite of the same sample $(0.39 \%)$, due to the hydrogen-rich nature of the former $(24,25)$. Maturation of the altered sediments, however, was clearly indicated by increased reflectance with temperature, especially above $275^{\circ} \mathrm{C}$ (Figure 6), and $R_{0}$ reached a maximum of $0.95 \%$ in the $360^{\circ} \mathrm{C}$ altered sediment samples.

Results from CPMAS ${ }^{13} \mathrm{C}$ NMR measurements of the altered sediments and kerogens are listed in Table 3 and illustrated in Figure $6 .{ }^{13} \mathrm{C}$ NMR spectra of the unheated and artificially matured kerogens are shown in Figure 7. The major band of the right portion of each spectrum (0-60 ppm) represents carbon in aliphatic structures including structures with sulfide bonds. The major band to the left of each spectrum represents carbon in aromatic (90-160 ppm) structures (including thiophenes), and in any carboxylate $(-180 \mathrm{ppm})$ and carbonyl $(-210 \mathrm{ppm})$ structures that may be present. Very little variation was observed in the ${ }^{13} \mathrm{C} N M R$ results from the altered sediment, kerogen and $\mathrm{CrCl}_{2}$-treated kerogen from the same experiments (Table 3, Figure 6). Comparison of the ${ }^{13} \mathrm{C}$ NMR spectra from each experiment, however, clearly show a preferential loss of aliphatic carbons relative to aromatic carbons with increasing temperature (Figure 7). Examination of Figure 6 reveals an exponential relationship between temperature and aromaticity with a major steepening in the curve above $275^{\circ} \mathrm{C}$.

Partial FID and FPD chromatograms from flash pyrolysis $\left(610^{\circ} \mathrm{C}\right)$ of the unheated, 250,300 and $360^{\circ} \mathrm{C}$ kerogens are shown in Figure 8. FPD peak assignments were made by comparison of relative retention times to earlier studies $(26,18)$, and are listed in Table 4 with the inferred carbon skeletons of the bound precursors (10). The major peaks in the FD chromatograms are due to $n$-alkanes and $n$-alkenes, alkylbenzenes and thiophenes (Figure 8 ). The Py-GC results indicate a preferential loss of aromatic and especially thiophenic compounds relative to $n$-hydrocarbons with increasing temperature. The generation potential for $n$-alkanes and $n$-alkenes remains high until approximately $300^{\circ} \mathrm{C}$ suggesting that $\mathrm{C}-\mathrm{C}$ cracking has not occurred to a significint extent below this temperature. 
Above $325^{\circ} \mathrm{C}$ essentially only gaseous products $\left(\mathrm{CH}_{4}, \mathrm{C}_{2} \mathrm{H}=\mathrm{C}_{2} \mathrm{H}_{4}, \mathrm{H}_{2} \mathrm{~S}\right)$ were detected in the flash pyrolyzates.

Estimates of the relative abundance of volatile thiophenic versus hydrocarbon pyrolysis products were made from the ratio of FID peak areas for 2-methylthiophene (2MT) to the sum of toluene (Tol) and $n$ - $\mathrm{C}_{7}$ alkene $\left(\mathrm{C}_{7} \mathrm{H}_{14}\right)$ (Figure 9). The $2 \mathrm{MT} /\left(\mathrm{Tol}+\mathrm{C}_{7} \mathrm{H}_{14}\right)$ ratio decreased slightly with increased temperature up to $250^{\circ} \mathrm{C}$. At temperatures greater than $250^{\circ} \mathrm{C}$. the ratio decreased sharply and approached zero above $325^{\circ} \mathrm{C}$. Although kerogens from the experiments below $250^{\circ} \mathrm{C}$ exhibited very little change in the $2 \mathrm{MT} /\left(\mathrm{Tol}+\mathrm{C}_{7} \mathrm{H}_{14}\right)$ ratio, the S/C ratio decreased significantly (from 0.051 to 0.032 ) relative to the unheated sample (Figure 9). Conversely, a sharper decrease in the $2 \mathrm{MT} /\left(\mathrm{Tol}+\mathrm{C}_{7} \mathrm{H}_{14}\right)$ ratio above $250^{\circ} \mathrm{C}$ coincided with only a moderate change in the S/C ratio (Figure 9).

The predominant sulfur-containing pyrolysis products in all FPD chromatograms were $\mathrm{H}_{2} \mathrm{~S}$ and low molecular weight thiophenes (Figure 8). $\mathrm{H}_{2} \mathrm{~S}$ was likely derived from the thermal decomposition of pyrite, present in the kerogen, as well as from the cleavage of organically-bound thiols, aliphatic sulfides (thiolanes, thianes) or sulfide bridges (18). Volatile thiophenic pyrolysis products were observed in the kerogens from all the experimental temperatures except for the 350 and $360^{\circ} \mathrm{C}$ experiments (Figure 8). At temperatures $\angle 300^{\circ} \mathrm{C}$ no marked changes in the internal distribution of thiophenic products were observed. At $300^{\circ} \mathrm{C}$ and above, however, the relative contribution of 2-methylthiophene, 2,5-dimethylthiophene, 2-ethyl-5methylthiophene and 2-methyl-5-propylthiophene decreased more dramatically than other thiophenic products (Figure 8).

Normalized (K-edge) XANES spectra of the $\mathrm{CrCl}_{2}$-treated kerogens are illustrated in Figure 4. With increased temperature a sharpening in the shape of the major peak occurred, as well as a slight $(-1 \mathrm{eV})$ shift towards higher energy. This shift is detectable at $175^{\circ} \mathrm{C}$ and clearly evident by $225^{\circ} \mathrm{C}$ (Figure 4). The percentages of the major forms of sulfur (normalized to $\% \mathrm{~S}$ ) in the kerogen determined by fitting of the XANES spectra are illustrated in Figure 5 . The primary sulfur forms present in the unheated kerogen were organic sulfides and polysulfides. Together these two species account for $\sim 50 \%$ of the sulfur while, thiophenes and sulfoxides comprised the majority of the remaining sulfur. Systematic changes in sulfur speciation as a function of temperature are clearly evident (Figure 5). Similar to the bitumen, thiophenes and sulfoxides present in the kerogens remained relatively constant with increased temperature. In contrast, organic sulfides and polysulfides decreased with temperature from 4.7 to $0.4 \%$ in the unheated and $360^{\circ} \mathrm{C}$ pyrite-free kerogens, respectively (Figure 5) with two marked decreases occurring above $175^{\circ} \mathrm{C}$ and $250^{\circ} \mathrm{C}$. Above $250^{\circ} \mathrm{C}$ the relative proportion of thiophenic sulfur exceeded that present as organic sulfides. 


\section{Discussion}

Compositional Characteristics of Unheated Monterey Shale Kerogen. The values obtained from bituminite reflectance $\left(\% \mathrm{R}_{0}=0.25\right)$. solid-state CP/MAS ${ }^{13} \mathrm{C}$ NMR spectroscopy (aromaticity $=0.34$ ) and Rock-Eval $\left(T_{\max }=386^{\circ} \mathrm{C}\right.$ ) measurements all indicate that the unheated Monterey kerogen was relatively immature. In addition, with an atomic $S_{\text {org }} / C$ ratio of 0.051 the sulfur-rich Monterey kerogen (Wt.\%S = 9.45) can be classified as "Type II-S" (5).

The homologous series of $n$-alkanes and $n$-alkenes present in the partial Py-GCFID chromatogram of the unheated Monterey kerogen sample is typical of a wide range of oil-prone. immature kerogens (27). The distinguishing feature of Monterey shale and other sulfur-rich kerogens, however, is the high relative abundance of thiophenes released during pyrolysis $(26,27)$. The thiophenic pyrolysis products detected by FPD can provide direct information regarding the chemical nature of macromolecularly bound sulfur $(10,20)$. When pyrolysis is conducted using wires with a Curie temperature of $610^{\circ} \mathrm{C}, \mathrm{S}-\mathrm{S}, \mathrm{C}-\mathrm{S}$ and C-C bonds are cleaved and sulfurbound or sulfur-containing moieties present in the kerogen will generate a variety of products through $\beta$-cleavage, $\gamma$-hydrogen rearrangement and by $\gamma$-cleavage $(10)$. Based on the substitution patterns of the thiophenes and benzothiophenes yielded upon pyrolysis, carbon skeletons of different sulfur-containing moieties originally present in the kerogen can be distinguished (10). Similar to previous studies of Monterey shale and other immature Type II-S kerogens $(18,26)$, a significant proportion of the sulfur-containing pyrolysis products from the unheated Monterey kerogen are likely derived from isoprenoid and/or steroidal carbon skeletons (Figure 8, Table 4).

Complementary information regarding the sulfur-containing structures present in the kerogen can be obtained through $\mathrm{x}$-ray absorption (XANES) spectroscopy. In addition, XANES spectroscopy allows all forms of sulfur present in the sample to be "seen", whereas pyrolysis only liberates volatile species. In contrast to the flashpyrolysis approach, XANES spectroscopy reveals the electronic environment of the sulfur atom and does not provide information on the configuration of carbon atoms, other than those in close proximity to sulfur. The XANES data reveal that organic sulfides and polysulfides, thiophenes and sulfoxides comprise 4.7, 2.3 and 0.9 weight percent of the unheated, $\mathrm{CrCl}_{2}$-treated kerogen, respectively (Figure 5). Thus, sulfides and polysulfides account for $>50 \%$ of the total sulfur in the unheated kerogen. The low percentage of sulfoxides indicates that oxidation of sulfur during sample manipulation was minor. K-edge XANES spectra do not allow for the discrimination between cyclic (thiolanes, thianes) and acyclic sulfides. By assuming, however, that the relative proportion of cyclic and acyclic sulfides is approximately equivalent, the ratio of thiophenes (a cyclic form of sulfur) to total sulfides can be used as an estimate of the extent of intra-versus inter-molecular Sbonding (18). Based on this premise, XANES spectrosiopic analysis of the unheated Monterey kerogen would indicate that sulfur cross-linking is extensive and that there are abundant, potentially weak S-linkages where thermally-induced cleavage might occur. 
Transformations During Laboratory Maturation. In order to constrain sources and sinks of sulfur as a function of temperature. we have calculated the fraction of the total sedimentary sulfur present in three major phases: kerogen, bitumen and total inorganic sulfur (Figure 10). The latter pool is calculated by difference assuming a closed system and an initial total sedimentary $S$ content (3.86\%; Table 2) and is predominantly composed of $\mathrm{H}_{2} \mathrm{~S}$, pyrite and pyrrhotite. For comparison, the distribution of carbon associated with gaseous species $\left(C_{1}-C_{3}\right.$ hydrocarbons, $\mathrm{CO}_{2}$ ), bitumen and kerogen are also shown in Figure 10. Plotting the data in this way shows several interesting trends which reveal systematic transformations in the concentrations and speciation of sulfur in each of the phases analyzed. These transformations also reveal the interplay between each phase during the maturation process.

In the unheated sediment the dominant portion (ca. 75\%) of the sedimentary $S$ is associated with kerogen, pyritic sulfur representing the remainder. Essentially no sulfur is associated with indigenous bitumen since extractable material was removed from the immature starting material (it is also assumed there is initially a negligible amount of adsorbed $\mathrm{H}_{2} \mathrm{~S}$ ). This condition prevails at temperatures up to $150^{\circ} \mathrm{C}$, above which the proportion of kerogen-bound sulfur decreases markedly from 3.0 to $1.8 \%$ at $225^{\circ} \mathrm{C}$. Only a minor increase in solvent extractable sulfur was observed over this temperature interval, and accordingly the loss of kerogen sulfur. is balanced by the production of inorganic sulfur. Above $250^{\circ} \mathrm{C}$ a further decrease in kerogen sulfur is apparent, and this is accompanied by an increase in bitumen sulfur, which peaked at $275^{\circ} \mathrm{C}$. This maximum also corresponds with the temperature of maximum bitumen generation (Figure 2) and, in particular, polar compound evolution. Above $275^{\circ} \mathrm{C}, \mathrm{S}$ in both bitumen and kerogen decreases resulting in an increase in inorganic sulfur. The total decrease of kerogen sulfur from the unheated sample to the $360^{\circ} \mathrm{C}$ residue was approximately a factor of 4 (i.e. 2.8 to $0.7 \%$ ).

Based on this mass balance information, and the compositional transformations observed, we can construct an overview of the likely fate of organically-bound sulfur during laboratory maturation of the Monterey shale. The earliest transformations occur at very low $\left(\leq 175^{\circ} \mathrm{C}\right)$ temperatures (in terms of artificial maturation experiments). This change has not been studied in detail previously, since it occurs well below the temperature at which the primary generation of hydrocarbon-like products takes place during laboratory heating experiments $(3,7)$. The decrease in kerogen sulfur implies that a substantial degree of internal rearrangement takes place within the kerogen macromolecular network, even under mild thermal stress. These rearrangements do not result in significant amounts of soluble (petroleum-like) products, but $\mathrm{H}_{2} \mathrm{~S}$ is generated. We postulate that the $\mathrm{H}_{2} \mathrm{~S}$ is primarily an elimination product from polysulfide bridges within the kerogen.

Cleavage of bridges containing 2 or more S-atoms would yield $\mathrm{H}_{2} \mathrm{~S}$ and the bridge may subsequently reform, the result being negligible release of soluble organic products. Alternatively, sulfide bridges could be broken. yielding $\mathrm{H}_{2} \mathrm{~S}$, but insufficient bridges are broken to release soluble. carbon-containing moieties from 
the kerogen. Whatever the case, the net result is a loss of suliur from the kerogen with no concomitant carbon loss. Based on the XANES analyses it is clear that the sulfur is removed from the kerogen during these "low temperature" experiments primarily as sulfides or polysulfides (Figure 5). This is also evident from the pyrolysis-based thiophene ratios, which show no decrease o:er this temperature interval (Figure 9). Both these observations are consister: with (poly)sulfide bridges as the reactive sulfur species. Unfortunately K-edge XANES does not allow unequivocal distinction of mono-sulfide from polysulnide species so this inference cannot be verified quantitatively. Nevertheless, qual;:ative support for the low-temperature reactivity of polysulfides is apparent in the normalized (K-edge) XANES spectra of the kerogens (Figure 4). Above $175^{\circ} \mathrm{C}$ the:e is a $\sim 1 \mathrm{eV}$ shift in the maximum for the lowest energy peak towards higher enerzy. Because organic polysulfides exhibit slightly lower K-edge energies than corresponding monosulfides this shift suggests preferential removal of polysulfides over mono-sulfides at lower temperatures.

Between $225^{\circ} \mathrm{C}$ and $300^{\circ} \mathrm{C}$ a significant proportion of the ke:ogen is converted to polar-rich bitumen (Figure 2). Polar compounds (resins and asphaltenes) are considered to be large, soluble macromolecules with a strong genetic link to kerogen (i.e. soluble kerogen moieties) (28). The bitumen generated at $275^{\circ} \mathrm{C}$ is enriched in sulfur compared to both lower and higher tempera:ure soluble products and, based on the XANES data, is dominated by (poly)sulfide sulfur. We interpret these data to imply that the bitumen derived from these experiments is predominantly the result of cleavage of sulfide links in the kerogen, liberating lower molecular weight (and therefore soluble) kerogen sub-fragments which retain abundant sulfide linkages within their infrastructure. Since sulfur in the newly generated bitumen cannot account for all of the sulfur los: from the kerogen, continued $\mathrm{H}_{2} \mathrm{~S}$ formation at these temperatures is also implied.

At higher temperatures $\left(>300^{\circ} \mathrm{C}\right)$ bitumen formation via cleavage of sulfur links gives way to hydrocarbon generation through $\mathrm{C}-\mathrm{C}$ bond scission. Presumably hydrocarbons are generated from both the kerogen and bitumen. These conditions result in soluble products which contain increasing proportions of aliphatic and aromatic hydrocarbons (including aromatized sulfur compounds) with maximum yields observed at $325^{\circ} \mathrm{C}$ for the former and $360^{\circ} \mathrm{C}$ for the later (Figure 2). The temperature regime between 275 and $360^{\circ} \mathrm{C}$ is also where the most marked changes in the carbon structure of the kerogen occurred, as indicated by bituminite reflectance and NMR spectrometry, which suggest increasing aromaticity. Also of note is the dramatic reduction in abundance of (poly)sulfide sulfur in the kerogen (Figure 5). In terms of relative proportions, thiophenic sulfur exceeds that of sulfidic sulfur above $250^{\circ} \mathrm{C}$ in the kerogen.

The distribution of carbon in the various pools resultin maturation of Monterey shale (Figure 10) is consistent with the above interpretation of the fate of organic sulfur during maturation. It is expec:ed that the relative concentration of organic carbon associated with the kerogen $C$ would decrease as bitumen and gaseous products are generated. Although this held true for experiments at $250^{\circ} \mathrm{C}$ and above, an increase in kerogen $\mathrm{C}$ ove: that of the unheated 
sample was observed at $125-175^{\circ} \mathrm{C}$. This was likely due to the low-temperature dissolution of non-carbon containing minerals originally present in the Monterey shale (e.g. refractory phosphates). Overall, kerogen $C$ decreased from approximately 21 to $15 \%$ in the unheated and $360^{\circ} \mathrm{C}$ samples. respectively (Figure 10), while gaseous organic carbon, in particular $\mathrm{CH}_{4}$ and $\mathrm{CO}_{2}$, increased with increasing temperature. Very little $(<1 \%)$ organic carbon was associated with the bitumen $\mathrm{C}$ until $250^{\circ} \mathrm{C}$, with a maximum in bitumen $\mathrm{C}$ at $275^{\circ} \mathrm{C}$ (Figure 10). This is consistent with the thermally induced cleavage of sulfide links in the kerogen freeing soluble, carbon-containing structures to the bitumen. At higher temperatures $\mathrm{C}-\mathrm{C}$ bonds in these soluble structures are likely broken leading to hydrocarbon and ultimately gas generation.

The generation of petroleum-like products as a function of temperature during the experiments presented here is consistent with previous experimental studies on sulfur-rich kerogens. The formation of expelled oil has been modeled as a two step process involving the decomposition of generated bitumen to form a compositionally distinct oil phase $(3,7)$. Although we cannot distinguish between generated bitumen and expelled oil in our experiments, compositional variations in the total extractable bitumen support such a model. Bitumen, as defined by Lewan (14), is rich in polar compounds relative to expelled oil. which contains substantially greater proportions of saturate and aromatic hydrocarbons. During our experiments we observed a clear offset between peak generation of polar compounds at $\left(275^{\circ} \mathrm{C}\right)$ and aliphatic and aromatic compounds $\left(325-360^{\circ} \mathrm{C}\right)$, consistent with early bitumen generation which in tum decomposes to produce a more oil-like substance. These temperatures for peak bitumen and inferred oil formation are significantly lower than those from hydrous-pyrolysis ( $72 \mathrm{hrs}$ ) of the relatively sulfur-poor Woodford shale $\left(330\right.$ and $350^{\circ} \mathrm{C}$, respectively) and the Phosphoria shale $\left(300\right.$ and $\left.350^{\circ} \mathrm{C}\right)$, characterized by an intermediate organic sulfur content (3). Baskin and Peters (7) conducted hydrous-pyrolysis experiments for 72 hrs utilizing the Monterey shale and observed peak bitumen and oil formation at 280 and $330^{\circ} \mathrm{C}$, respectively. These temperatures are almost identical to those observed during this study, the difference in heating time notwithstanding. Taken collectively, the experimental results provide strong evidence for the early generation of bitumen and oil from sulfur-rich kerogens, relative to sulfur-poor kerogen, owing to the preferential cleavage of weak sulfur linkages.

Interpreting the above results within the context of geological maturation of sulfur-rich source rocks such as the Monterey Fm., we can make several inferences. The first concerns the general phenomenon of low temperature petroleum generation. We have observed relatively low temperatures (experimentallyspeaking) for maximum bitumen generation $\left(275^{\circ} \mathrm{C}\right)$ during our experiments. This maximum reflects the liberation (or formation) of sulfur-rich high molecular weight heterocompounds (polar compounds) which clearly indicates the transfer of a significant proportion of sulfur from insoluble kerogen to soluble bitumen. Even before this event, however, partial elimination of sulfur from the kerogen takes place under mild thermal stress $\left(175^{\circ} \mathrm{C}\right)$, and there is ever: reason to believe that this also occurs in the natural system within a late diagenetic/early maturation time- 
frame. For both of these phases of sulfur removal from the kerogen, geochemical evidence suggests that the sulfur species responsible are sulfide linkages. Initially, polysulfide bridges may collapse, liberating $\mathrm{H}_{2} \mathrm{~S}$, but little or no bitumen (Figure 10). These bridges are likely to be the most thermally labile. Subsequently, C-S bonds in mono-sulfide bridges may undergo scission in concert with S-S bond cleavage, releasing polar-rich bitumen. Thus (poly)sulfide linkages are the species which display the greatest reactivity at lower temperatures and likely play a key role in dictating the evolution of petroleum-like products. At higher temperatures, reactions dominated by sulfur bond-breakage give way to those involving carboncarbon bond scission (Figure 10). Here we envisage that sulfur plays a subordinate role owing to the fact that most of the labile sulfur is already eliminated from the kerogen at lower temperatures and condensed cyclic forms of sulfur, which are thermodynamically more stable and do not participate significantly in hydrocarbon generation, are more prevalent.

An interesting observation stemming from the present study is the non-linear relationship between the Py-GC based thiophene ratio and $S_{\mathrm{crz}} / C$ ratio as a function of maturation temperature. A near linear relationship has previously been observed between these parameters for immature kerogens (27). Eglinton et al. (18) also observed this relationship for unconsolidated organic sulfur-rich sediments from the Peru margin, noting that the relation held despite the fact that XANES analysis indicated only a small proportion of the sulfur was thiophenic. These authors postulated that the ratio must reflect total sulfur because of a constancy in the relative abundance of sulfur species over the diagenetic interval studied. Indeed, for Peru margin kerogens, XANES-based speciation was remarkably constant, with sulfides dominating throughout. Like the Peru kerogens, the kerogens from the unheated Monterey shale showed a similar dominance of sulfides, but unlike the former there was a significant shift in the relative proportions of sulfur species as a function of temperature. Consequently, at lower temperatures $\left(<250^{\circ} \mathrm{C}\right)$, the thiophene ratio remained constant while the S/C ratio decreased (Figure 9). This reflects removal of $S$ from polysulfide bridges (as $\mathrm{H}_{2} \mathrm{~S}$ ), while sulfur more intimately associated with carbon structures remains intact. At higher temperatures, the thiophene ratio shows a more precipitous reduction compared to the S/C ratio, where removal of thiophenic species becomes prevalent. The result of these thermally disparate events is a "dog-leg" relationship between the thiophene ratio and the S/C ratio. Although systematic decreases in the thiophene ratio as a function of maturity have been previously observed (29). this more complex relationship with respect to the S/C ratio has not been reported. It is clear, therefore, that caution should be exercized when using the Py-GC approach for estimating organic sulfur contents of kerogens spanning a wide maturity range.

\section{Conclusions}

Hydrous-pyrolysis experiments, when combined with an analytical scheme involving XANES spectroscopy, Py-GC, CP/MAS ${ }^{13} \mathrm{C}$ NMR spectrometry, elemental analysis, TLC-FID and relected light microscopy. represents an effective means to determine the speciation of sulfur during maturation of the Monterey 
shale. The following conclusions regarding gross and molecular-level transformations in sulfur speciation and the manner by which they lead to the early conversion of kerogen to bitumen and oil are made:

1. The high sulfur content of Monterey kerogen leads to relatively low temperature (polar) bitumen $\left(275^{\circ} \mathrm{C}\right)$ and (saturate and aromatic hydrocarbons) oil $\left(325-360^{\circ} \mathrm{C}\right)$ generation as compared to sulfur-poor kerogens during experiments.

2. XANES spectroscopic analyses indicate that sulfides and polysulfides are the major forms of organic sulfur initially present in the Monterey Shale kerogen. Removal of these sulfur species from the kerogen begins at very low temperatures $\left(150^{\circ} \mathrm{C}\right)$, with qualitative evidence indicating preferential elimination of polysulfides. The relative amount of organic sulfides and polysulfides increases in the bitumen fraction to a maximum at $275^{\circ} \mathrm{C}$, whereas the relative proportion of total thiophenes in both the kerogen and bitumen fractions show comparatively little change with temperature. The early generation of bitumen is attributed to the inherent weakness of sulfur linkages within kerogen-bound sulfides and, in particular, polysulfides.

3. The fate of organic sulfur during laboratory thermal maturation of Monterey kerogen can be described in terms of three temperature regimes: (a) $150-225^{\circ} \mathrm{C}$ : (Poly)sulfide bridges collapse, leading to the formation of $\mathrm{H}_{2} \mathrm{~S}$. (b) $225-275^{\circ} \mathrm{C}$ : Scission of sufficient sulfide linkages resulting in the release of soluble sulfur-rich fragments (bitumen) from the kerogen and continued $\mathrm{H}_{2} \mathrm{~S}$ production. (c) $>275^{\circ} \mathrm{C}$ : Cleavage of S-S and C-S bonds gives way to $\mathrm{C}-\mathrm{C}$ bond scission and the generation of saturated and aromatic hydrocarbons. At higher temperatures $\left(360^{\circ} \mathrm{C}\right)$ sulfur may no longer be mechanistically important as most of the labile forms have been removed.

\section{Acknowledgments}

The authors would like to thank M. D. Lewan (USGS, Denver, CO) for providing the Monterey Shale sample, S. Wang and F. Lo (BNL, Upton, NY) for assisting with XANES analysis and curve fitting, L. B. Eglinton and N. L. Parmentier for various analyses, and $E$. Bailey for help with manuscript preparation. This research was funded by U.S. Department of Energy grant \#'s DE-FGO2-86ER13466 (J. K. Whelan, J.S.S.), DE-FGO2-92ER14232 (T.LE.), DE-AC02-76CH00016 (A.V.) and DE-FC21-93MC30127 (F.P.M.) This is Woods Hole Oceanographic Institution contribution number 8948 .

\section{Literature Cited}

1. Tissot B. Revue de l'Institut Francais du Petrol. 1984, 39, 561-572.

2. Tannenbaum E. and Aizenshtat Z. Org. Geochem. 1984, 6, 503-511.

3. Lewan M.D. Phil. Trans. R. Soc. Lond. A315, 1985, 123-134.

4. Gransch J.A. and Posthuma J. In: Advances in Organic Geochemistry; Tissot, B. and Bienner, F.. Eds.; Paris Editions Technip: Paris. 1974: pp 727-739.

5. Orr W.L. Org. Geochem. 1986, 10, 499-516. 
6. Hunt J.M., Lewan M.D. and Hennet R.J-C. Bull. Amer. Assoc. Petrol. Geol. 1991, 75, 795-807.

7. Baskin D.K. and Peters K.E. Bull. Amer. Assoc. Petrol. Geol. 1992, 76, 1-13.

8. Patience R.L, Mann A.L. and Poplett I.J.F. Geochim. Cosmochim. Acta 1992, 56, 2725-2742.

9. Lovering E.G. and Laidler K.J. Canadian Jour. Chem. 1960, 38, 2367.

10. Sinninghe Damsté J.S., Eglinton T.I., de Leeuw J.W. and Schenck P.A. Geochim. Cosmochim. Acta 1989, 53, 873-889.

11. Sinninghe Damsté J.S., Rijpstra W.I.C., Kock-van Dalen A.C., de Leeuw J.W. and Schenck P.A. Geochim. Cosmochim. Acta 1989, 53. 1343-1355.

12. Orr W.L. and Sinninghe Damste J.S. In: Geochemistr. of Sulfur in Fossil Fuels; Orr, W.L. and White, C.M., Eds.; ACS Symposium Series 429, 1990; pp. 2-24.

13. Claxton M.J., Patience R.L. and Park P.J.D. In: Poster sessions from the $16^{\text {th }}$ International meeting on Organic Geochemistry; Stavanger: 1993; pp. 198201.

14. Lewan M.D. In: Organic Geochemistry Principles and Applications; Engel, M.H. and Macko, S.A., Eds: Plenum Press: New York. 1993; pp. 419-442,.

15. Eglinton T.I. and Douglas A.G. Energy and Fuels 1988, 2. 81-88.

16. Canfield D.E., Raiswell R., Westrich J.T., Reaves C.M.. Berner R.A. Chem. Geol. 1986, 54, 149-155.

17. Acholla F.V. and Orr W.L. Energy and Fuels 1993, 7, 406-410.

18. Eglinton T.I., Irvine J.E., Vairavamurthy A., Zhou W. and Manowitz B. Org. Geochem. 1994, 22, 781-799.

19. Vairavamurthy A., Manowitz B., Zhou W. and Jeon Y In: Environmental Geochemistry of Sulfide Oxidation; Alpers, C.N. and Blowes, D.W. Eds.; ACS Symposium Series 550; 1994; pp. 412-430.

20. Waldo G.S., Carlson R.M.K., Moldowan J.M., Peters K.E. and Penner-Hahn J.E. Geochim. Cosmochim. Acta 1991, 55, 801-814.

21. Teichmuller M. Org. Geochem. 1986, 10, 581-599.

22. Karlsen D.A. and Larter S.R. Org. Geochem. 1991, 17, 603-617.

23. Seewald J.S. and Seyfried W.E. Earth Planet. Sci. Lett. 1990, 101, 388-403.

24. Robert P. In: Organic Metamorphism and Geothermal History; D. Reidel Publishing Co.: Holland, 1988; pp. 61-129,.

25. Lo H.B. Org. Geochem. 1993, 20, 653-657.

26. Eglinton T.I., Sinninghe Damsté J.S., Pool W., de Leeuw J.W., Eijkel G. and Boon J.J.. Geochim. Cosmochim. Acta 1992, 56, 1545-1560.

27. Eglinton T.I., Sinninghe Damsté J.S., Kohnen M.E.L. and de Leeuw J.W. Fuel 1990, 69, 1394-1404.

28. Sinninghe Damsté J.S. and de Leeuw J.W. Org. Geochiem. 1990, 16, 10771101 .

29. Eglinton T.I., Sinninghe-Damste J.S., Kohnen M.E.L., de Leeuw J.W., Larter S.R. and Patience R.L. In: Geochemistry of Sulfur in Fissil Fuels: Orr, W.L. and White. C.M. Eds.; ACS Symposium Series 429; 1900: pp. 529-565. 
Table 1. Total extract, saturated, aromatic and polar compound yiclds. Concentrations of dissolved $\mathrm{CO}_{2}+\mathrm{C}_{1} \cdot \mathrm{C}_{3}$ (light hydrocarbon) and $\mathrm{H}_{2} \mathrm{~S}$.

\begin{tabular}{|c|c|c|c|c|c|c|}
\hline Trmperature $\left({ }^{\circ} \mathrm{C}\right)$ & $\begin{array}{c}\text { Total } \\
\text { (mg/g rock) }\end{array}$ & $\begin{array}{c}\text { Saturates } \\
\text { (mg/g rock) }\end{array}$ & $\begin{array}{l}\text { Aromatics } \\
\text { (mg/g rock) }\end{array}$ & $\begin{array}{c}\text { Polars } \\
\text { (mg/g rock) }\end{array}$ & $\begin{array}{c}\mathrm{CO}_{2}+\mathrm{C}_{1} \cdot \mathrm{C}_{3} * \\
(\mathrm{mg} / \mathrm{g} \text { rock })\end{array}$ & $\begin{array}{c}\mathrm{H}_{2} \mathrm{~S}^{*} \\
(\mathrm{mg} / \mathrm{g} \text { rock) }\end{array}$ \\
\hline Linheated & 10.7 & 0.0 & 0.0 & 10.7 & n.d. & n.d. \\
\hline 125 & 1.23 & 0.0 & 0.0 & 1.23 & 6.01 & n.d. \\
\hline 150 & 1.72 & 0.0 & 0.0 & 1.72 & 8.68 & n.d. \\
\hline 175 & 7.26 & 0.58 & 0.0 & 6.68 & 13.3 & n.d. \\
\hline 200 & 22.4 & 0.11 & 0.27 & 22.0 & 20.7 & n.d. \\
\hline$=25$ & 10.5 & 0.64 & 0.87 & 9.01 & n.d. & n.d. \\
\hline 30 & 36.9 & 0.54 & 2.08 & 34.2 & 29.8 & 6.9 \\
\hline$=75$ & 68.4 & 2.69 & 3.70 & 62.0 & n.d. & n.d. \\
\hline$\equiv \infty$ & 29.7 & 1.60 & 1.45 & 26.6 & 47.9 & 8.4 \\
\hline$\$ 25$ & 29.2 & 3.25 & 4.39 & 215 & 50.3 & 9.3 \\
\hline$\$ 50$ & 22.7 & 1.87 & 3.26 & 17.5 & 69.3 & 12.7 \\
\hline$\equiv 60$ & 33.1 & 1.21 & 4.81 & 27.1 & 77.4 & 18.8 \\
\hline
\end{tabular}

-.d. not determined.

$=$ calculated from the concentrations of these species dissolved in the aqueous phase. 
'Tiulle 2. Rilimeritul Anulyals of loulk sediments, $\operatorname{Cr}\left(:_{2}\right.$-Irculed kerogens and solvent (bltumen) extracts

\begin{tabular}{|c|c|c|c|c|c|c|c|c|c|c|c|c|c|c|}
\hline \multirow[b]{2}{*}{ Temp. $\left({ }^{\circ} \mathrm{C}\right)$} & \multicolumn{4}{|c|}{ Bulk Sediment } & \multicolumn{5}{|c|}{$\mathrm{CrCl}_{2}$-treated Kerogen } & \multicolumn{5}{|c|}{ Bitumen } \\
\hline & $\% 0 \mathrm{C}$ & $\% N$ & $\% S$ & S/C & \%OC & \%H & $\% \mathbf{N}$ & \%S & $\mathbf{S} / \mathbf{C}$ & $\% O C$ & $\% \mathbf{H}$ & $\% N$ & $\% s$ & S/C \\
\hline Unhealed. & 20.58 & 1.24 & 3.86 & 0.070 & 60.44 & 6.52 & 3.22 & 8.25 & 0.051 & 68.86 & 8.34 & 2.05 & 7.25 & 0.039 \\
\hline 125 & 22.60 & 1.36 & 3.67 & 0.061 & 59.83 & 6.41 & 3.06 & 7.83 & 0.049 & 56.40 & 5.67 & 2.44 & 5.12 & 0.034 \\
\hline 150 & 23.54 & 1.42 & 3.67 & 0.058 & 59.57 & 6.86 & 2.91 & 7.50 & 0.047 & 67.68 & 7.02 & 2.23 & 6.92 & 0.038 \\
\hline 175 & 22.39 & 1.34 & 3.50 & 0.059 & 60.79 & 6.22 & 3.11 & 7.39 & 0.046 & 69.62 & 8.39 & 1.56 & 8.30 & 0.045 \\
\hline 200 & 22.62 & 1.23 & 3.02 & 0.050 & 64.56 & 6.45 & 3.14 & 6.92 & 0.040 & n.d. & n.d. & n.d. & n.d. & n.d. \\
\hline $225^{*}$ & 18.64 & 1.08 & 2.64 & 0.053 & 62.88 & 6.28 & 3.24 & 6.04 & 0.036 & 55.35 & 4.69 & 1.76 & 6.79 & 0.046 \\
\hline 250 & 20.32 & 1.21 & 3.06 & 0.056 & 60.81 & 5.99 & 2.93 & 5.21 & 0.032 & 68.66 & 7.59 & 1.68 & 10.8 & 0.059 \\
\hline $275^{*}$ & 15.58 & 0.94 & 2.36 & 0.057 & 69.13 & 5.74 & 3.60 & 4.49 & 0.024 & 71.98 & 8.25 & 2.27 & 10.4 & 0.054 \\
\hline 300 & 18.31 & 1.12 & 2.24 & 0.046 & 72.55 & 5.66 & 3.70 & 3.91 & 0.020 & 55.95 & 6.72 & 1.35 & 6.61 & 0.044 \\
\hline 325 & 16.71 & 0.97 & 2.21 & 0.050 & 75.26 & 5.03 & 3.95 & 3.40 & 0.017 & 72.55 & 7.92 & 1.62 & 9.64 & 0.050 \\
\hline 350 & 15.08 & 0.90 & 1.81 & 0.045 & 65.22 & 4.39 & 3.54 & 2.94 & 0.017 & n.d. & n.d. & n.d. & n.d. & n.d. \\
\hline 360 & 14.58 & 0.98 & 2.44 & 0.063 & 74.79 & 4.23 & 4.01 & 3.48 & 0.017 & 76.48 & 6.86 & 2.06 & 7.61 & 0.037 \\
\hline
\end{tabular}

- Sediment samples were not decarbonated prior to hydrous-pyrolysis.

n.d. not determined. 
Table 3. NMR results of bulk sediments, isolated kerogens and $\mathrm{CrCl}_{2}$-treated kerogens and "bituminite" reflectance of bulk sediments

\begin{tabular}{|c|c|c|c|c|}
\hline \multirow[b]{2}{*}{ I emperature $\left({ }^{\circ} \mathrm{C}\right)$} & \multicolumn{3}{|c|}{ Aromaticity* } & \multirow{2}{*}{$\frac{\text { \% } R_{0}}{\text { Bulk }}$} \\
\hline & $\begin{array}{c}\text { Bulk } \\
\text { Sediment }\end{array}$ & Kerogen & $\begin{array}{c}\mathrm{CrCl}_{2} \text {-treated } \\
\text { Kerogen }\end{array}$ & \\
\hline Linheated & 0.35 & 0.34 & n.d. & 0.25 \\
\hline 125 & 0.32 & 0.35 & 0.32 & 0.24 \\
\hline 150 & 0.36 & 0.32 & 0.33 & 0.28 \\
\hline 175 & 0.41 & 0.37 & 0.36 & 0.31 \\
\hline$=00$ & n.d. & n.d. & n.d. & 0.30 \\
\hline 225 & 0.44 & n.d. & n.d. & 0.29 \\
\hline 250 & 0.45 & 0.49 & 0.49 & 0.36 \\
\hline 275 & 0.57 & n.d. & n.d. & 0.33 \\
\hline 300 & 0.64 & 0.59 & 0.63 & 0.42 \\
\hline$\$ 25$ & 0.67 & n.d. & n.d. & 0.59 \\
\hline$\equiv 50$ & n.d. & n.d. & n.d. & 0.85 \\
\hline$\equiv 60$ & 0.88 & 0.83 & 0.83 & 0.95 \\
\hline
\end{tabular}

- may include any contributions from carboxylate and carbonyl carbons if presezt.

z.d. not determined. 
Table 4. Peak identifications for FPD chromatograms

\begin{tabular}{|c|c|c|c|c|c|}
\hline Peak & Compound & Origin* & Peak & Compound & Origin \\
\hline 1 & Hydrogen sulfide & $?$ & 16 & 2-ech!1-methylthiophene & B \\
\hline ? & Thiophene & $?$ & 17 & 2.3.5-srmethylthiophene & I,B \\
\hline 3 & 2. Methylthiophene & L & 18 & 2-meth! 1-5-ethenylthiophene & L \\
\hline 4 & 3-Methylthiophene & 1 & 19 & 2.3.4:-imethylthiophene & B.S \\
\hline 5 & Thiolane & $?$ & 20 & 3-isoprof:1-2-methylthiophene & $S$ \\
\hline 6 & Methyldihydrothiophene & L & 21 & 2-mechy:-5-propylthiophene & L \\
\hline 7 & 2-methylthiolane & $\mathrm{L}$ & & +2.2 siethylthiophene & $\mathrm{L}$ \\
\hline 8 & 2-ethylthiolane & L & 22 & 5-ethyl-23-dimethylthiophene & B \\
\hline 9 & 2,5-dimethylthiophene & L & 23 & Unknown & S? \\
\hline 10 & 2,4-dimethylthiophene & $B, S$ & 24 & 2-butil-5-methylthiophene & L \\
\hline 11 & 2-ethenylthiophene & 1 & 25 & 2-ethyl-5-butylthiophene & L \\
\hline 12 & 2,3-dimethylthiophene & $\mathrm{I}, \mathrm{B}$ & 26 & 2-methyl-5-pentylthiophene & L \\
\hline 13 & 2-ethylthiolane & L & 27 & 2-meth!:benzo[ $[\beta]$ thophene & L \\
\hline 14 & 2-propylthiophene & L & 28 & 4-meth!:̈enzo[ $[\beta]$ thiophene & L \\
\hline 15 & 2-ethyl-5-methylthiophene & $\mathrm{L}$ & & + 3-mets: :Jenzo[ß]thiophene & B \\
\hline
\end{tabular}

- Inferred carbon skeleton of bound precursor: $L=$ linear. $B=$ branched. $I=150$ f:s:ooid, $S=$ steroid side chain. 
Figure 1. Outline of analytical scheme for separation and characterization of hydrous-pyrolysis products.

Figure 2. Bar charts showing yields of total extract, saturated, aromatic and polar compound classes for the soluble (bitumen) products from each hydrouspyrolysis experiment.

Figure 3. Variation in the atomic S/C ratio of the bitumen (open diamonds) and $\mathrm{CrCl}_{2}$-treated kerogens (closed stars) with temperature.

Figure 4. Normalized XANES spectra of (a) bitumen from the unheated, $125^{\circ} \mathrm{C}, 150^{\circ} \mathrm{C}, 175^{\circ} \mathrm{C}, 225^{\circ} \mathrm{C}, 250^{\circ} \mathrm{C}, 275^{\circ} \mathrm{C}, 300^{\circ} \mathrm{C}, 325^{\circ} \mathrm{C}, 350^{\circ} \mathrm{C}$ and $360^{\circ} \mathrm{C}$ hydrous-pyrolysis experiments, and (b) $\mathrm{CrCl}_{2}$-treated kerogens from the unheated, $125^{\circ} \mathrm{C}, 150^{\circ} \mathrm{C}, 175^{\circ} \mathrm{C}, 225^{\circ} \mathrm{C}, 250^{\circ} \mathrm{C}, 275^{\circ} \mathrm{C}, 300^{\circ} \mathrm{C}, 325^{\circ} \mathrm{C}$ and $360^{\circ} \mathrm{C}$ experiments.

Figure 5. XANES-based sulfur speciation in the (a) $\mathrm{CrCl}_{2}$-treated kerogen and (b) bitumen fractions.

Figure 6. Variation in aromaticity (may include any contributions from carboxylate carbons at $\sim 175 \mathrm{ppm}$ ) of kerogen, $\mathrm{CrCl}_{2}$-treated kerogen and altered sediment fractions as well as variation in reflectance of altered sediments with temperature. Symbols represent: (Aromaticity) open diamonds kerogens, open squares pyrite-free kerogen, closed circles altered sediments; $\left(\% \mathrm{R}_{\mathrm{o}}\right)$ closed stars altered sediments.

Figure 7. Solid-state ${ }^{13} \mathrm{C}$ CP-MAS NMR spectra of the kerogen isolates from the unheated, $125^{\circ} \mathrm{C}, 150^{\circ} \mathrm{C}, 175^{\circ} \mathrm{C}, 250^{\circ} \mathrm{C}, 325^{\circ} \mathrm{C}$ and $360^{\circ} \mathrm{C}$ experiments.

Figure 8. Partial (a) FID and (b) FPD chromatograms from Py-GC of the kerogen isolates from the unheated, $250^{\circ} \mathrm{C}, 300^{\circ} \mathrm{C}$ and $360^{\circ} \mathrm{C}$ hydrouspyrolysis experiments. In (a) numbers represent $n$-hydrocarbon homologs, symbols denote: closed circles alkylbenzenes, open circles thiophenes. Peak assignments for (b) are listed in Table 4.

Figure 9. Assessment of the relative abundance of thiophenes in Py-GC (FID) traces of $\mathrm{CrCl}_{2}$-treated kerogens from each hydrous-pyrolysis experiment (expressed as the ratio of [2-methylthiophene/(toluene+ $\left.\left.\mathrm{C}-\mathrm{H}_{14}\right)\right]$ ) with (a) temperature and (b) atomic $\mathrm{S} / \mathrm{C}$ ratio.

Figure 10. Variation in total sedimentary (a) sulfur and (b) carbon with temperature. 


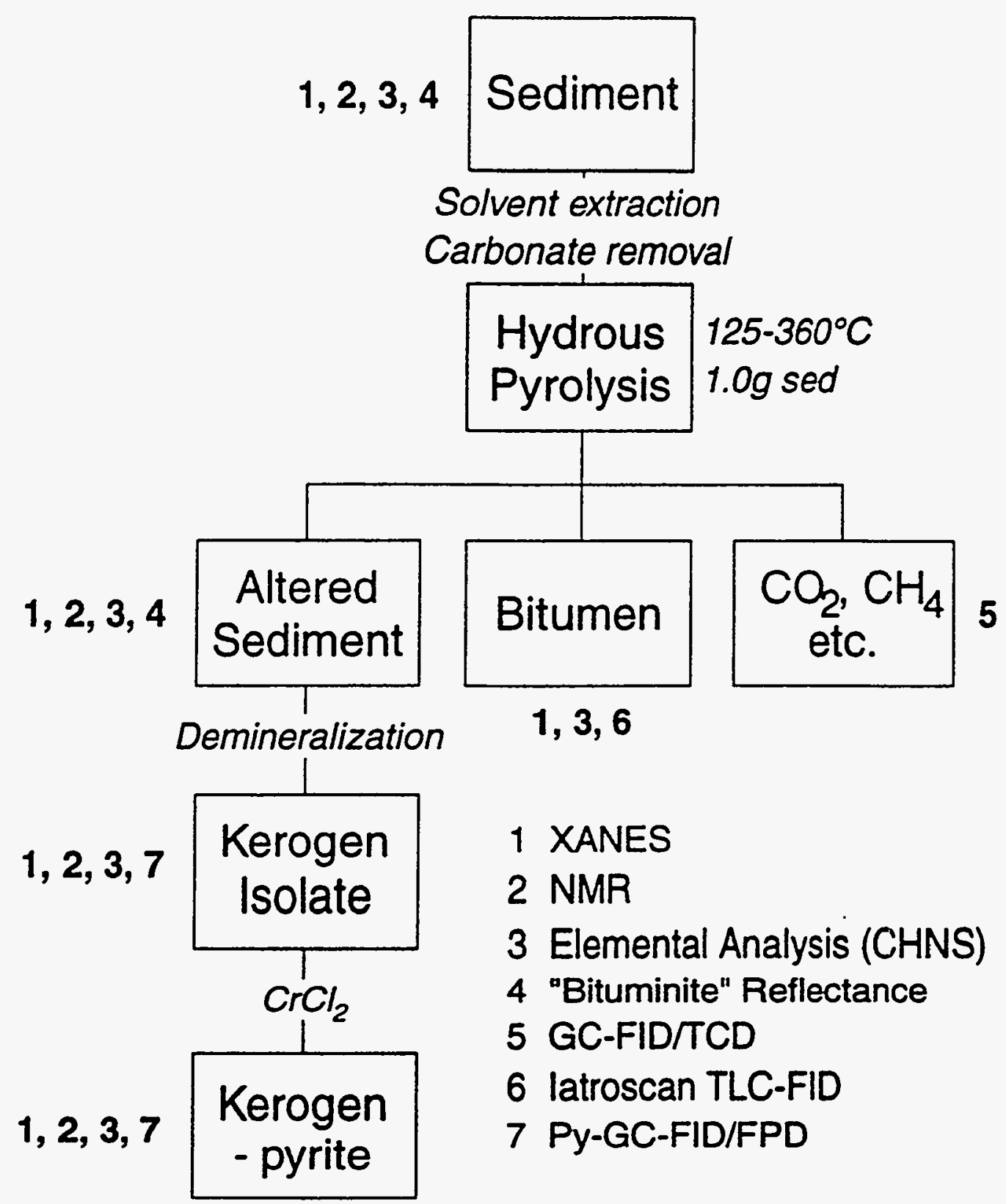




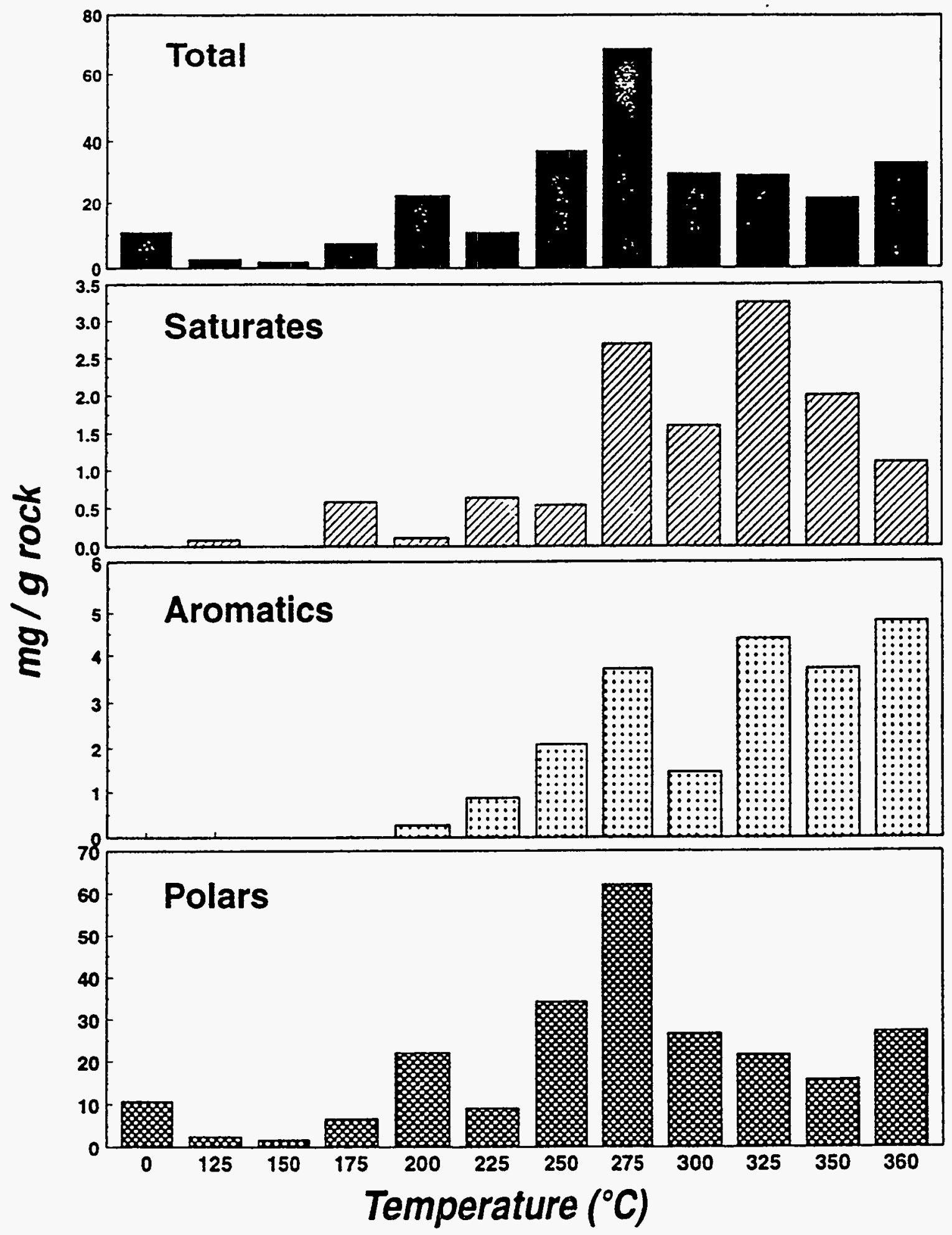




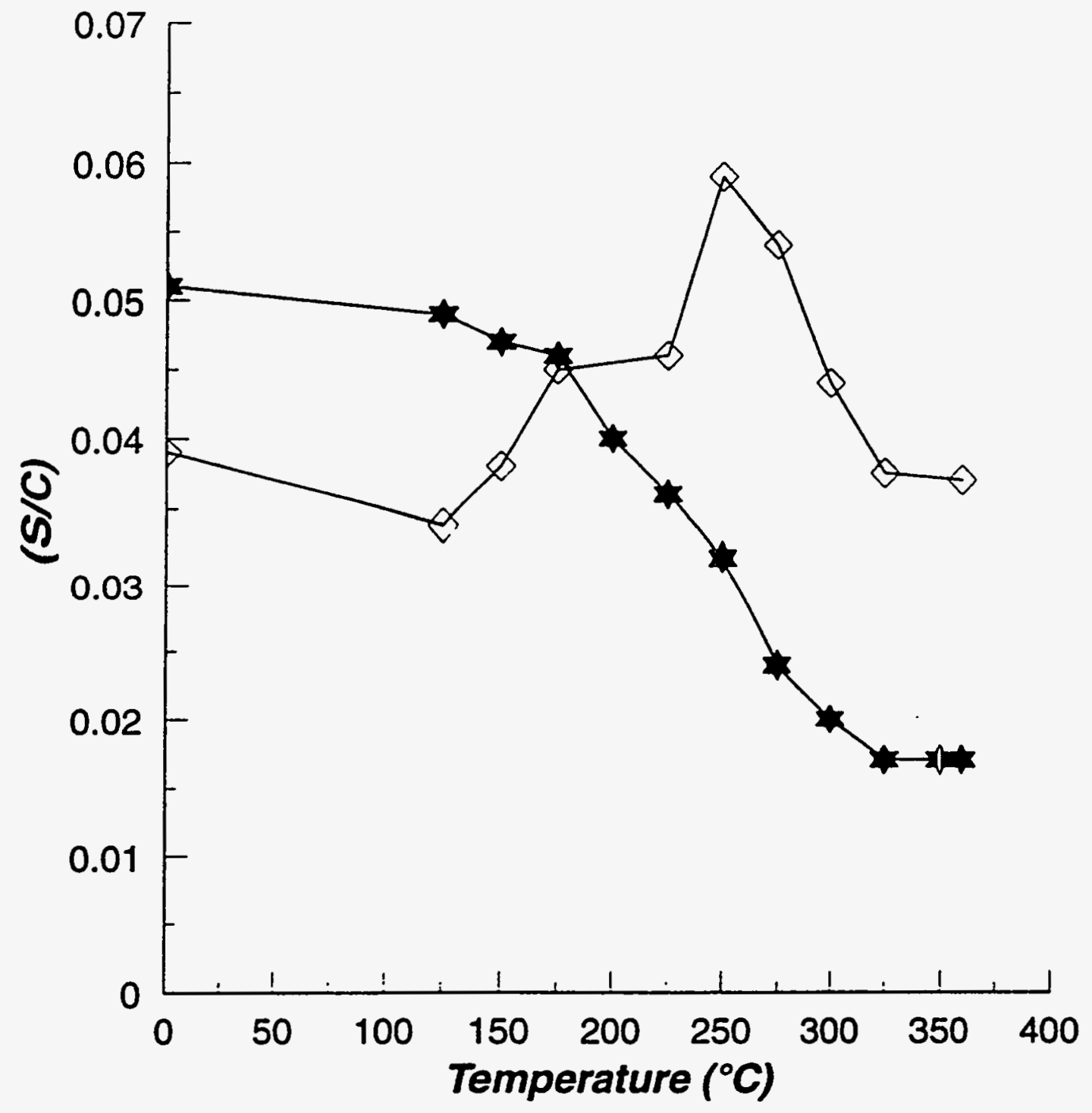


Bitumen

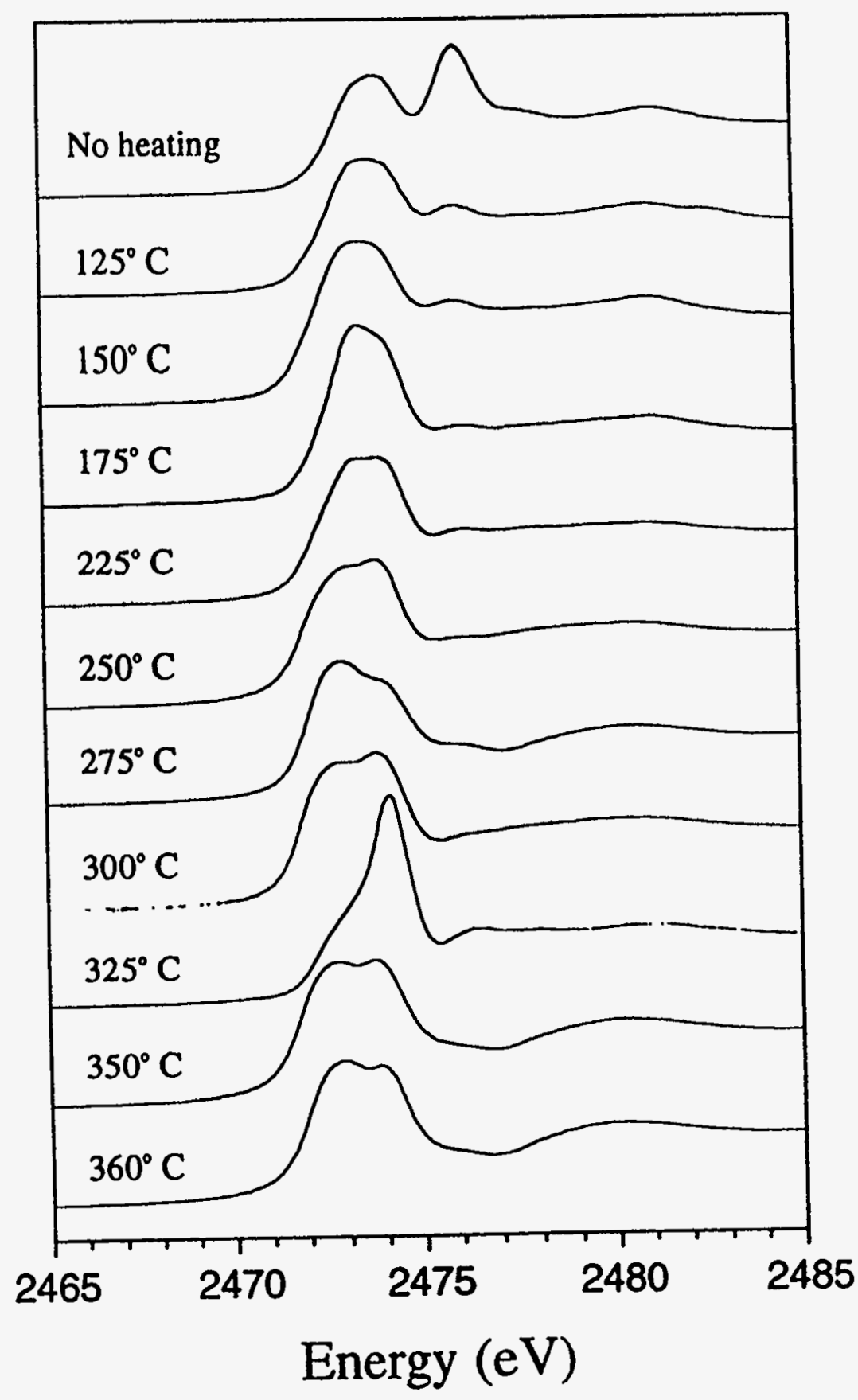

$\mathrm{CrCl}_{2}$-treated kerogen

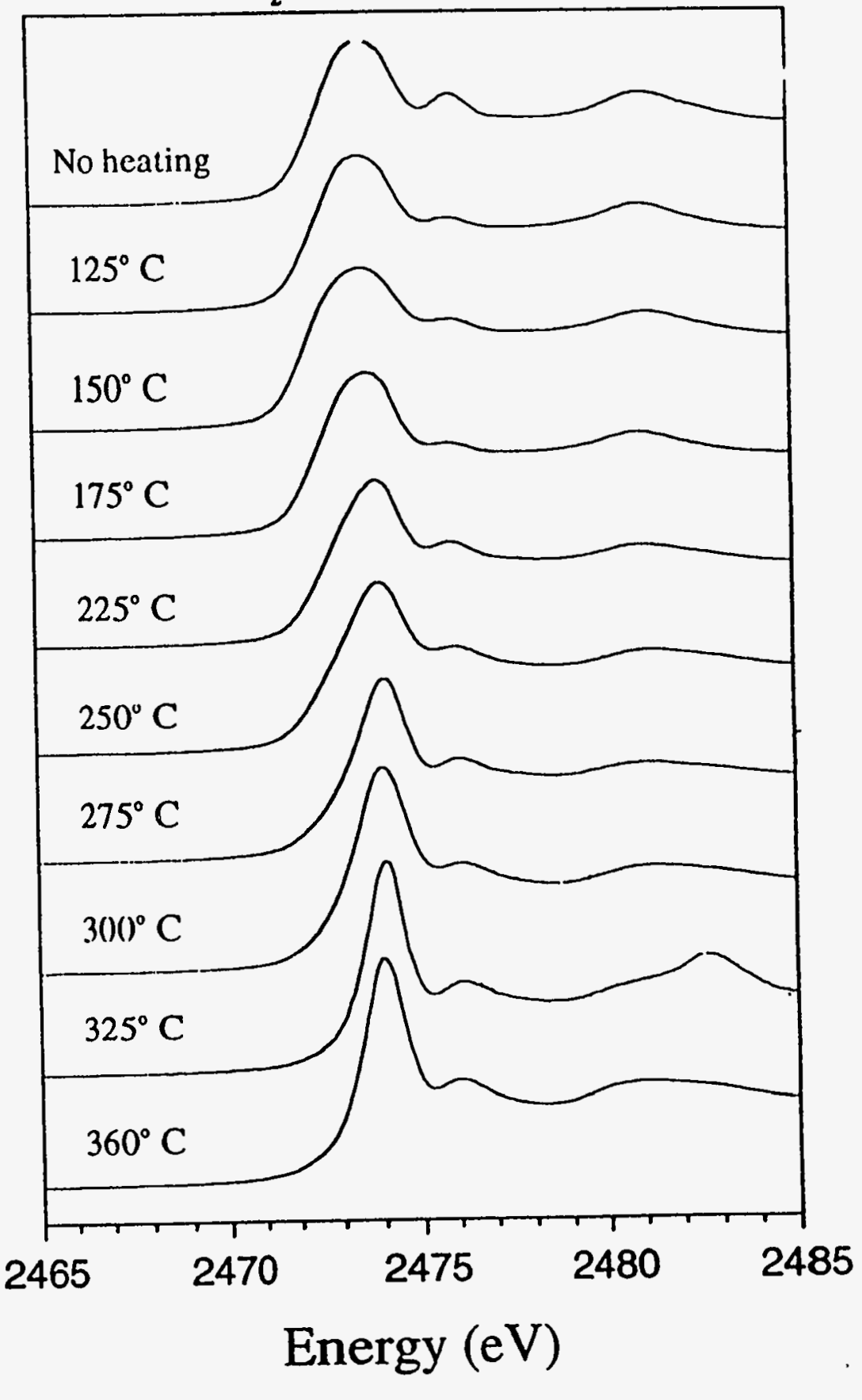



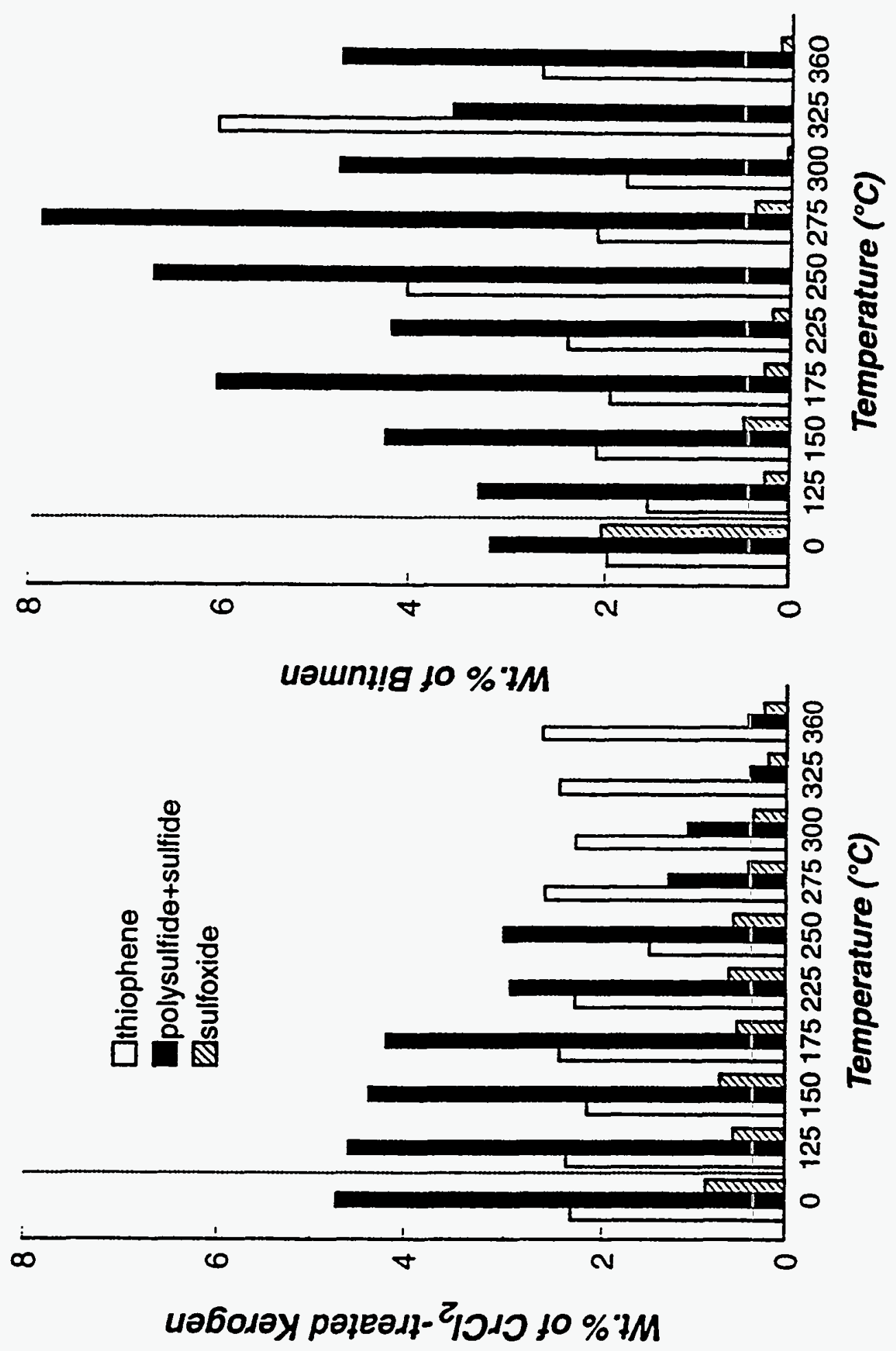


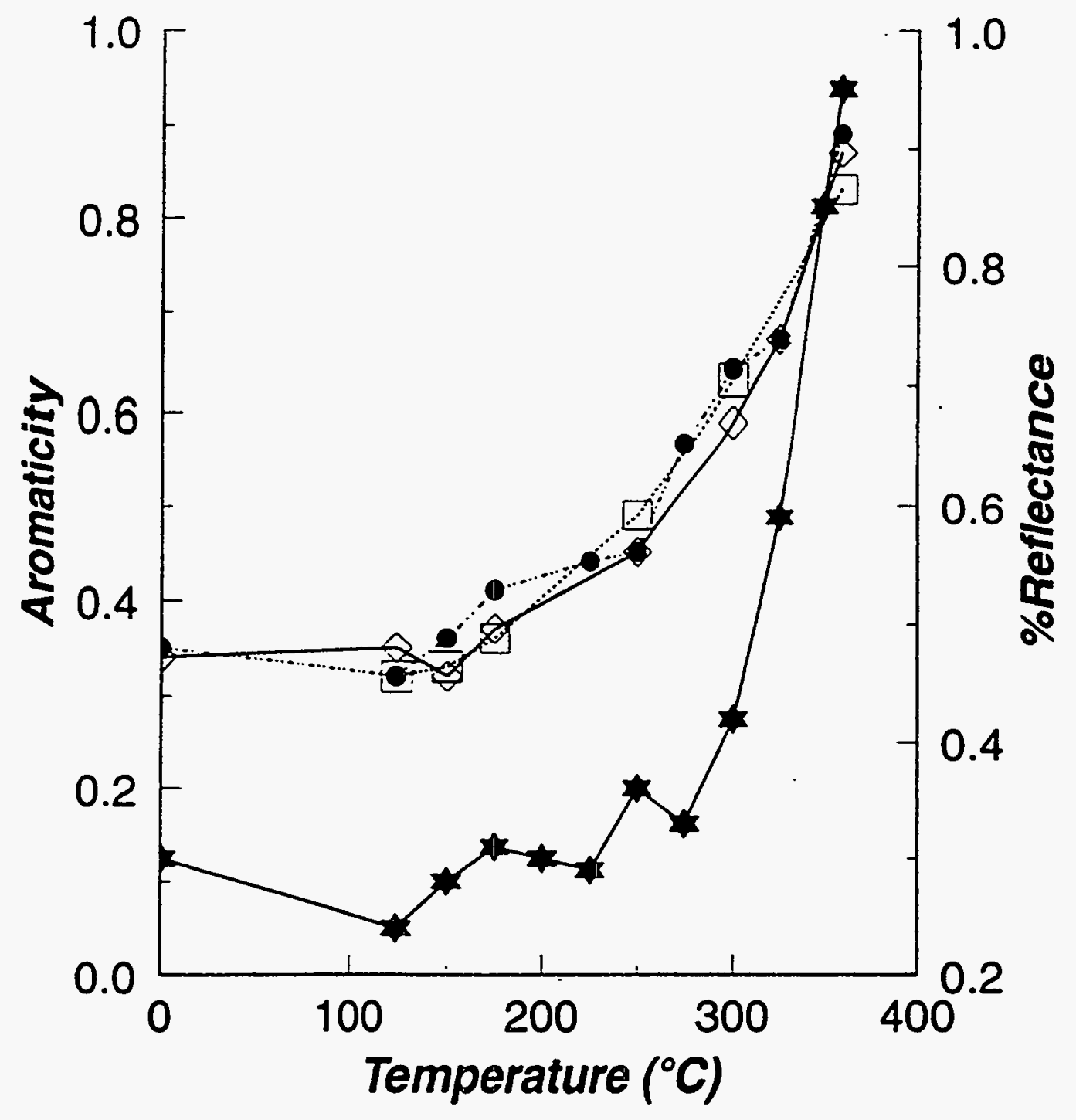




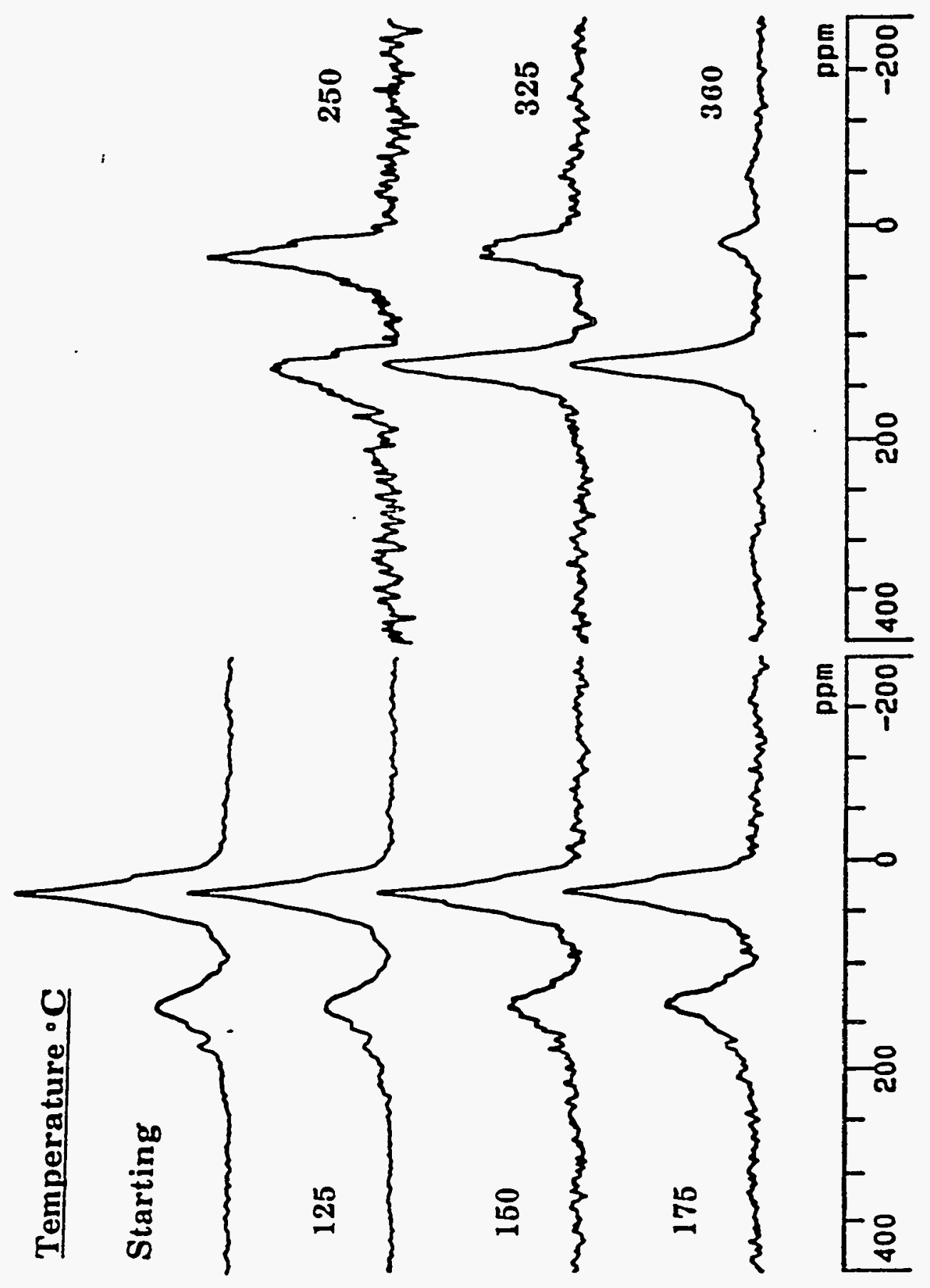



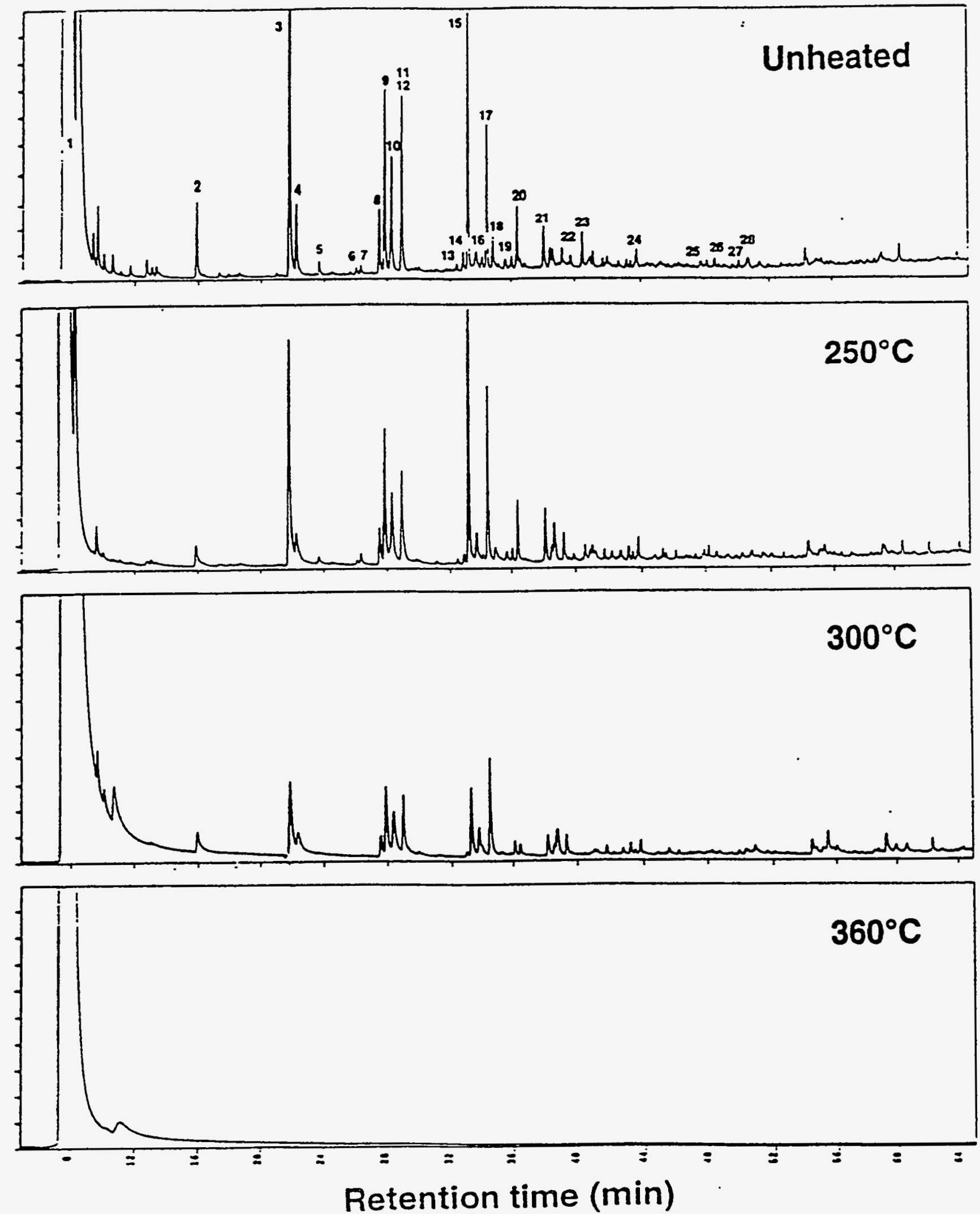

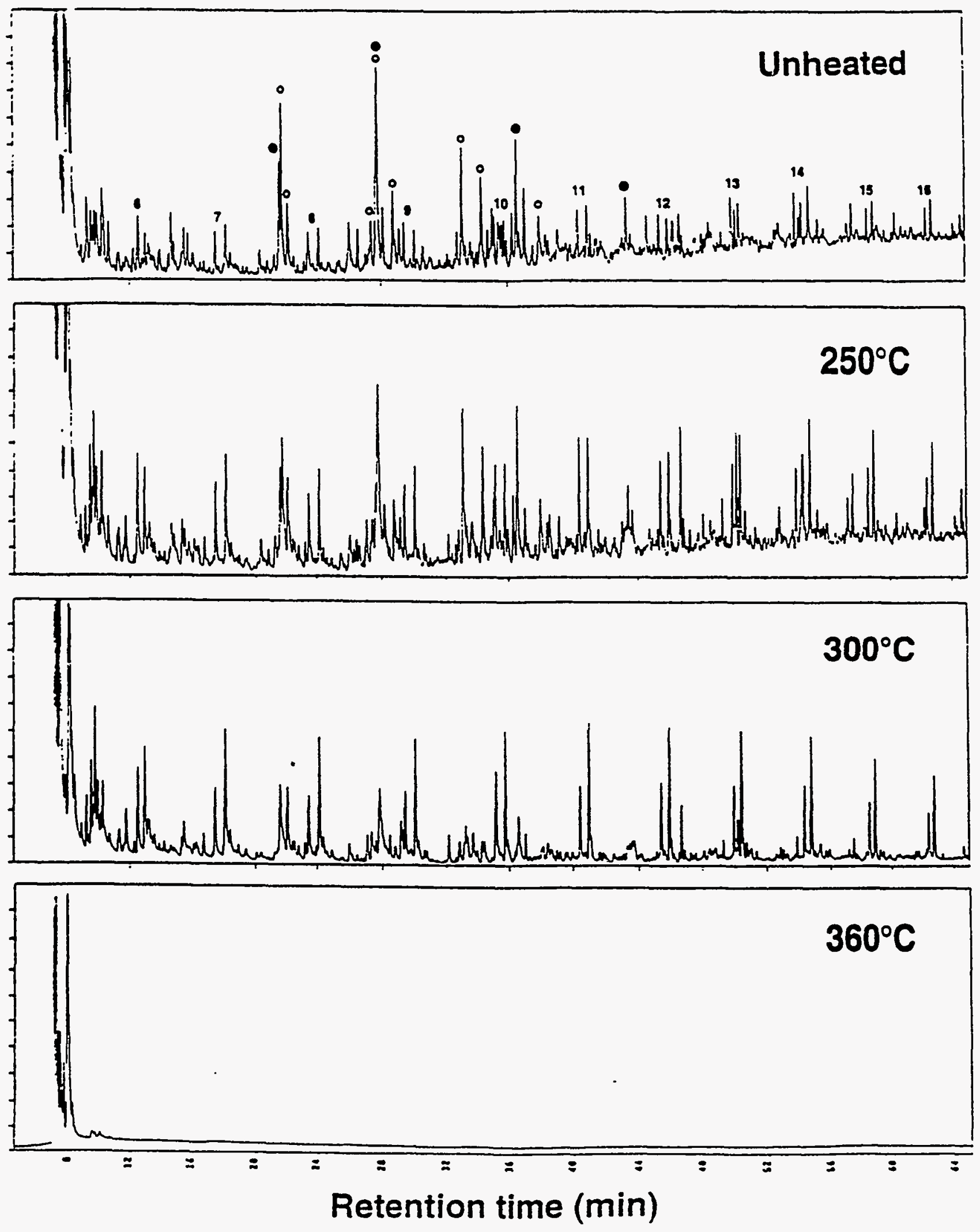

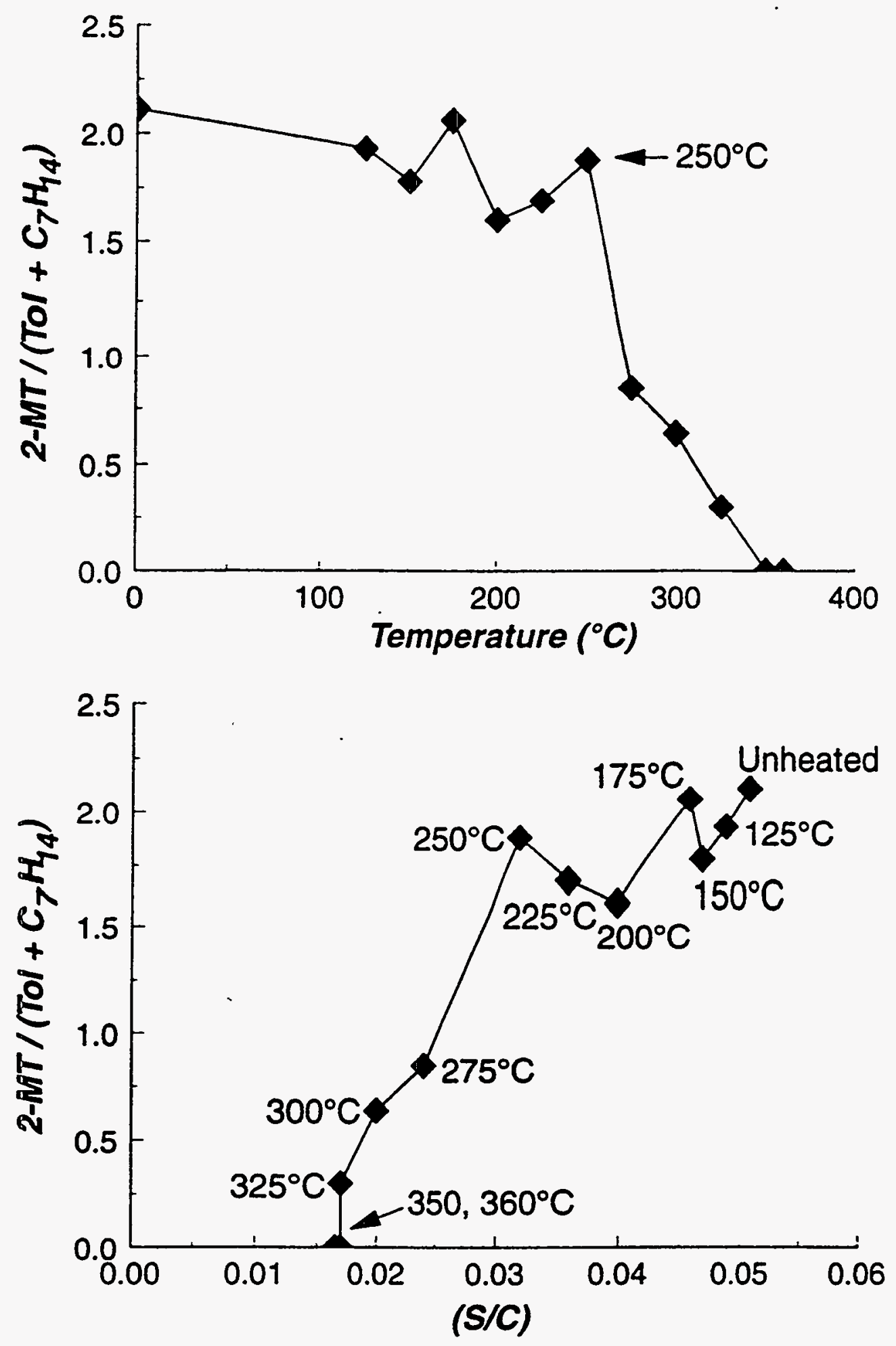

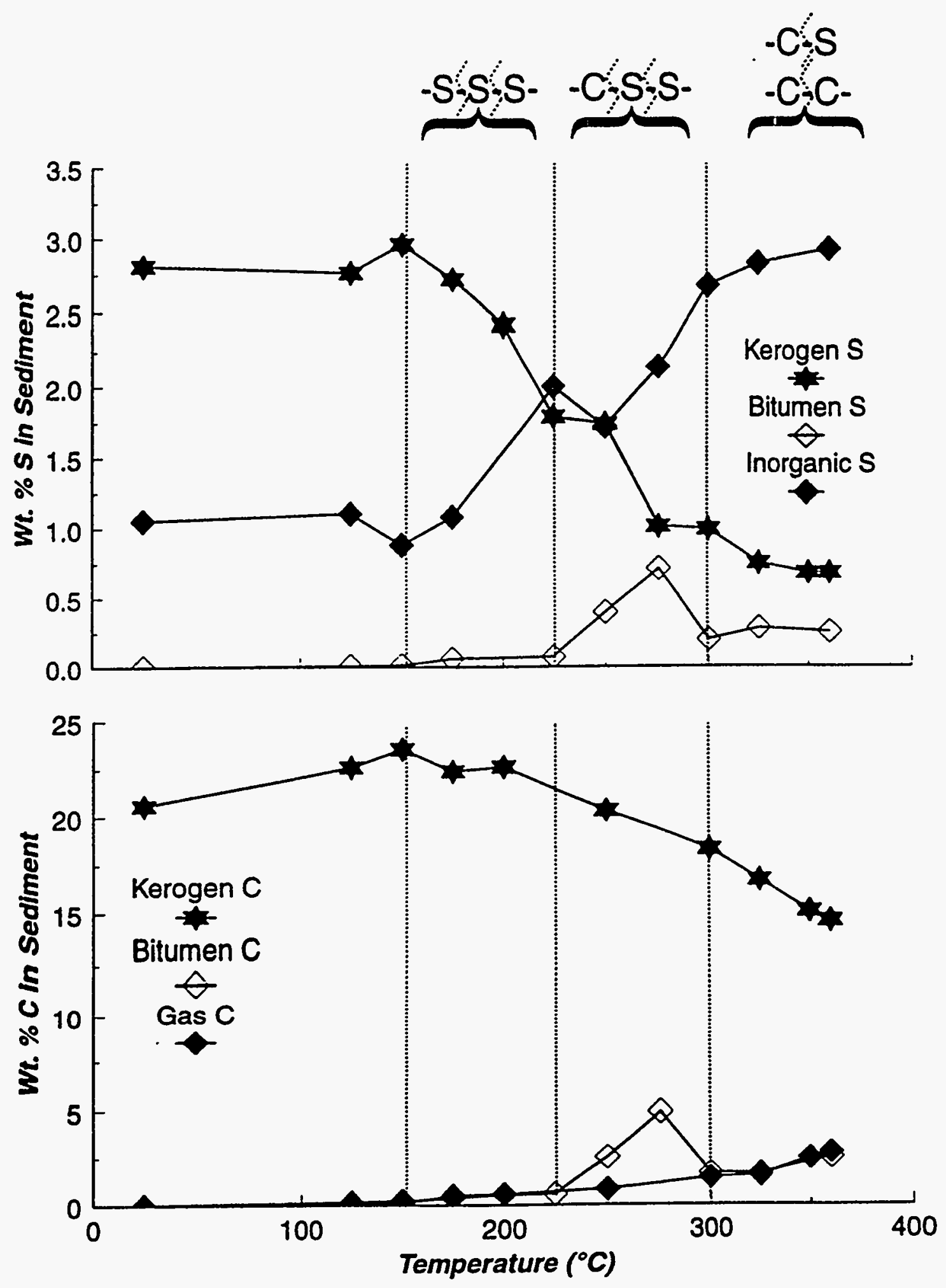